\title{
Growing Season Harvests of Shrub Willow Have Higher Nutrient Removals and Lower Yields Compared to Dormant Season Harvests
}

\section{Daniel PL de Souza}

SUNY-ESF: SUNY College of Environmental Science and Forestry

Mark Eisenbies ( $\square$ m.eisenbies@gmail.com)

SUNY-ESF: SUNY College of Environmental Science and Forestry https://orcid.org/0000-0002-83679762

\section{Timothy Volk}

SUNY-ESF: SUNY College of Environmental Science and Forestry

\section{Research Article}

Keywords: Short rotation woody crops, Salix, harvest timing, biomass production, nutrient management

Posted Date: January 19th, 2022

DOI: https://doi.org/10.21203/rs.3.rs-1251444/v1

License: (9) This work is licensed under a Creative Commons Attribution 4.0 International License. Read Full License 


\section{Abstract}

The commercial establishment of shrub willow biomass crops with three- or four-year harvest cycles raises concerns about nutrient removals. Furthermore, commercial harvesters in the northeast United States have begun to open the harvest season in late summer to early fall in order to ensure access on poorly drained, marginal sites because the ground no longer reliably freezes in winter. The potential impact that increased leaf-on harvesting has on nutrient export and its implications for crop management are not well known. This study examined the effects of six harvest dates over 10 months on the nutrient removal and second rotation biomass production of four shrub willow cultivars on a site in central New York State. First rotation harvests yielded between 77 and $85 \mathrm{Mg} \mathrm{ha}^{-1}$ during the growing season, and was between 93 and $104 \mathrm{Mg} \mathrm{ha}^{-1}$ after dormancy. There was a significant effect of harvest timing on the removal of $\mathrm{N}, \mathrm{K}, \mathrm{Ca}, \mathrm{Mg}$, and $\mathrm{S}$. Willow harvested in October removed comparatively higher amounts of $\mathrm{N}$ (77.1 kg ha $\left.{ }^{-1} \mathrm{y}^{-1}\right), \mathrm{P}\left(11.2 \mathrm{~kg} \mathrm{ha}^{-1} \mathrm{y}^{-1}\right), \mathrm{Ca}\left(163.7 \mathrm{~kg} \mathrm{ha}^{-1} \mathrm{y}^{-1}\right), \mathrm{Mg}\left(9.9 \mathrm{~kg} \mathrm{ha}^{-1} \mathrm{y}^{-1}\right)$, and S $\left(8.9 \mathrm{~kg} \mathrm{ha}^{-1} \mathrm{y}^{-1}\right)$ than in other harvests. Potassium removal was greater for plants harvested in June and August (51.2 and $52.5 \mathrm{~kg} \mathrm{ha}^{-1} \mathrm{y}^{-1}$ respectively). Significant interactions between harvest timing and cultivars suggest that targeted cultivar selection and deployment could maintain yields and limit excess nutrient losses.

\section{Introduction}

Short rotation woody crops (SRWC), including shrub willow, are considered potential biomass feedstocks to replace the fossil fuels that dominate energy supply in the U.S. [1, 2]. Initial establishment of willow crops at commercial scales has occurred in the U.S. [3, 4]. These deployments have been facilitated by research and improvements in the system through the development of high yielding cultivars, implementation of incentive programs, demonstration of environmental services and alternative applications, and opportunities to promote biodiversity and produce bioenergy [5-10]. Despite their potential and the improvements that have been achieved, a robust market for solid biomass crops has not thus far developed. A reliable supply and demand for biomass must be guaranteed in order to support such a market to be self-sustaining. In the meantime, research related to shrub willow management harvesting impacts should continue in order to ensure that shrub willow producers could sustainably deliver biomass to end users year-round.

Concerns about the sustainability of intensively managed forests and their respective nutrient demands has existed for decades [11-13]. Obvious comparisons and concerns have extended to SRWC [14]. Harvesting of woody biomass in forests or SRWC removes nutrients from the site; if they are not replaced by fertilization or natural mineralization soil fertility may be impacted on sensitive sites and affect the long-term site productivity $[13,15,16]$. In addition, removal of material may disrupt crucial soil biological and ecological functions [17]. There are numerous strategies employed to reduce nutrient losses during forest biomass harvest operations: (a) retain adequate quantities of slash (coarse and fine woody debris) on-site; (b) retain or leave tree foliage on-site to retain nutrients; and (c) replace removed nutrients by fertilizing biomass sites with wood-ash or other sources [18]. Existing cut-and-chip harvest operations in 
short rotation willow leave from 2.5 to $6.1 \mathrm{Mg} \mathrm{ha}^{-1}$ on $95 \%$ of the area within a site, which generally accounts for 6 to $22 \%$ of the harvested biomass [19-21], although these values can be higher under some conditions $[19,22]$. Regardless of the amounts, the predominant recommendation for harvesting shrub willow is that it occur after leaf fall and before bud set to reduce nutrient removal at harvest [23]. This timing allows some nutrients to be translocated from the leaves to the root system and stem, or returned to the soil as litter fall [1].

In practice, commercial harvests have not necessarily occurred within the recommended window; site conditions, especially on poorly drained marginal land in the northeast U.S., may limit machine access and operators may elect to expand the harvesting window [24]. The timing of willow harvests can potentially impact coppice regeneration and regrowth, and ultimately impact the productivity and costs [19]. The effect of timing of harvest on coppice has arisen as a key research question and which may have different implications across regions, and among SRWC species [25-29], including shrub willow cultivars. However, the phenotypic variation in coppicing relative to harvest timing is not fully understood [25]. Dormant-season harvest is recommended to ensure maximum sprout vigor, compared to growingseason harvest, given the higher availability of carbohydrate reserves in roots after leaf fall, which will support the initial growth of new sprouts after harvest [26]. The initial growth rate of shrub willow coppiced stems is very dependent on solar radiation, temperature, and water availability, however, studies have shown that the vigor of sprouts and the sprouting ability severely decreased when plants were harvested during an actively growing stage $[25,26,30]$.

\section{Objective}

While most existing guidelines for shrub willow suggest harvests occur when trees are dormant [18, 23], there is not much information about the impact on productivity and nutrient removal when harvest is conducted during the growing season. In practice, harvesting schedules are difficult to predict because they are subject to ground conditions, weather, and machine availability, which may delay, hinder, or even preclude activities at an optimal time for the crop. Shrub willow crops in central New York State (NY) are frequently planted on marginal agricultural land, which is generally due to poor site drainage as opposed to fertility issues. Another key aspect of dormant season harvests in NY is that the weight of machines is better supported on frozen ground, which enhances mobility and prevents soil displacement [18, 23]. However, temperatures of sufficient duration to freeze the ground in central and northern NY have become increasingly unreliable. The extended freezes that are required often occur after the first significant snowfalls, which insulates the ground and prevents it from hardening to a sufficient depth for equipment. Commercial willow growers have responded to these changing circumstances by initiating their harvest operations as early as mid-August to ensure access to the scheduled acreage. In principle, leaf-on harvests remove additional above ground biomass and nutrients, which could impact the long-term productivity of the site. Given the operational realities and importance of nutrient management strategies that ensure the system's production over multiple coppice cycles, the objective of this project is to evaluate the effects the harvest timing on nutrient removal and above ground biomass production for several cultivars of shrub willow crops in central NY. 


\section{Materials And Methods \\ Site description}

A willow stand located in Canastota, NY $\left(43^{\circ} 03^{\prime} 05^{\prime \prime} \mathrm{N}, 075^{\circ} 44^{\prime} 19^{\prime \prime} \mathrm{W}\right)$ was established in the spring of 2002. The soils at the site are classified as Cazenovia and Camillus silt loams (Fine-loamy, mixed, active, mesic Oxyaquic Hapludalfs and Fine-loamy, mixed, active, mesic Typic Eutrudepts) that are moderately well drained with a depth to water table ranging from 61 to $121 \mathrm{~cm}$, and a depth to bedrock of more than $200 \mathrm{~cm}[31,32]$. The climate is temperate humid and cold, with an mean annual precipitation ranging from 973-1017 mm [33]. Following guidelines at the time, a suite of six cultivars (Table 1) were planted in monoclonal blocks in double-rows with a spacing of $1.5 \mathrm{~m}$ between double-rows, $0.76 \mathrm{~m}$ within doublerows, and $0.6 \mathrm{~m}$ between plants (14,400 plants $\left.\mathrm{ha}^{-1}\right)$. The crop was coppiced after the first growing season to induce the growth and development of multiple sprouts per stool, and urea applied at a rate of $100 \mathrm{~kg} \mathrm{~N} \mathrm{ha}^{-1}$ at the beginning of the second growing season.

Table 1

Shrub willow cultivars included in the time of harvest study in Canastota, NY.

\begin{tabular}{|llll|}
\hline Cultivar ID & Diversity group & Species/pedigree & note \\
\hline $9882-25$ & PUR & S. purpurea & narrower strips \\
\hline $9870-40$ & MIYA & S. miyabeana & \\
$9871-41$ & MIYA & S. miyabeana & \\
\hline 95311 & ERIO & S. eriocephala & low survival, removed \\
\hline SX61 & MIYA & S. miyabeana & low survival, removed \\
\hline SX67 & MIYA & S. miyabeana & \\
\hline
\end{tabular}

Treatment plots were designated in each cultivar block after the first growing season (Figure 1). Plots consisted of five double rows in width $(11.4 \mathrm{~m})$ and length of 14 plants per double-row $(4.3 \mathrm{~m})$ for a total area of $49 \mathrm{~m}^{2}$. Due to insufficient rows on the westmost block (cultivar 9882-25), these treatment plots were narrowed to four double rows $(9.3 \mathrm{~m})$ and $40 \mathrm{~m}^{2}$ in area. Due to poor survival, two clones were treated, but not measured (cultivars 95311 and SX61). Measurement plots were established within each treatment area consisting of 18 plants (center three double-rows for 9870-40, 9871-41, and SX67 and two double-rows in the 9882-25 plots). Hence, the measurement plots were buffered within the treatment plots by one double-row one the east and west edges, three plants at the southern edge and one plant at the northern edge.

Phase 1 of the staged harvest plan prescribed that harvesting commence the summer of 2007, and gradually expose and remove treatment areas as the study progressed. Cutting on treatment plots progressed from south to north so that each cut would take place on the southern exposure of each 
replication (Figure 1). While this approach does release plants in subsequent plots, the purpose was to ensure equitable lighting for sprouts that emerge from willow stools soon after cutting. How nutrients are allocated to these sprouts and whether they are able to harden before winter is a critical consideration in this experiment. Additionally, the harvest plan dictated the stand surrounding the treatment areas was harvested mechanically in June at the same time as the first treatment plot to simulate clear-cut conditions, maximize light, and avoid extraneous and/or unequal shading effects on the remaining treatment areas. Thus, the ultimate experimental design consisted of a $6 \times 4$ timing $x$ cultivar $(T x C)$, stripstrip factorial experiment with three replications (blocks)(Table 2, Figure 1). Phase 2 of the plan consisted of a full-site, leaf-off harvest of second rotation growth that took place in December, 2011.

Table 2

Timing of harvest, age of plants in months, growing degree days (GDD) for each harvest date, and stage of plant growth used to study the impacts of timing of harvest on nutrient removal and coppice regrowth of shrub willow crops.

\begin{tabular}{|c|c|c|c|c|c|c|}
\hline Treatment & $\begin{array}{l}\text { Harvest } \\
\text { date }\end{array}$ & Plant stage & $\begin{array}{l}\text { Stem age } \\
2007 \text { (months) }\end{array}$ & $\begin{array}{l}\text { Rotation } \\
\text { GDD* }\end{array}$ & $\begin{array}{l}\text { Stem age } \\
2011 \\
\text { (months) }\end{array}$ & $\begin{array}{l}\text { Rotation } \\
\text { GDD* }\end{array}$ \\
\hline Jun & $\begin{array}{l}\text { Jun 6-8, } \\
2007\end{array}$ & $\begin{array}{l}\text { After full leaf } \\
\text { out }\end{array}$ & 54 & 7,187 & 54 & 6,745 \\
\hline Aug & $\begin{array}{l}\text { Aug, 2-8 } \\
2007\end{array}$ & After bud set & 56 & 7,739 & 52 & 6,146 \\
\hline Sep & $\begin{array}{l}\text { Sep } 13- \\
18,2007\end{array}$ & $\begin{array}{l}\text { Starting } \\
\text { senescence }\end{array}$ & 57 & 8,164 & 51 & 5,747 \\
\hline Oct & $\begin{array}{l}\text { Oct 15- } \\
19,2007\end{array}$ & $\begin{array}{l}\text { Mid-fall (leaves } \\
\text { dropping) }\end{array}$ & 58 & 8,366 & 50 & 5,552 \\
\hline Jan & $\begin{array}{l}\text { Jan 21- } \\
24,2008\end{array}$ & Dormant & 61 & 8,417 & 47 & 5,508 \\
\hline Apr & $\begin{array}{l}\text { Apr } 10- \\
14,2008\end{array}$ & $\begin{array}{l}\text { Before leaf out } \\
\text { began }\end{array}$ & 64 & 8,420 & 44 & 5,460 \\
\hline
\end{tabular}

\section{Harvest and sample collection activities}

Treatment areas were hand harvested with gas-powered brush saw on their prescribed dates (Table 2). Willow inside the measurement plot were cut 5 to $15 \mathrm{~cm}$ above the soil surface and the above ground parts of the plants were collected (stem, branches, twigs, and bark, and leaves), bundled, and weighed (scales suspended from tractor bucket) to estimate wet yield. Three stems were selected representing the range of diameters represented in the bundle (small, medium, and large, relative to the diameter range at each plot) and the leaves removed. These stem subsamples were subsequently chipped, weighed, and a 1 to $2 \mathrm{~kg}$ sample retained to determine gravimetric moisture content [34]. Leaf subsamples from leaf-on harvests, were weighed, bagged, and retained to determine gravimetric moisture content. Thus, leaf mass, stem mass, stem:leaf ratio, and moisture content could be estimated for each harvest date and scaled to 
a per hectare basis. Finally, all treatment plots were resampled for woody biomass in December 2011 using the same methodology that was used in 2007.

\section{Laboratory procedures}

Nutritional analyses of the biomass were performed on a subsample from the chips collected from each plot during the harvest. A 300-400 g, representative sample of dried chips were ground in a Willey Mill using a 40-mesh screen, and a 3-5 g subsample produced. Similarly, a 3-5 g sample of foliar material was also produced. Samples were sent to the Agricultural Analytical Services Lab at the Pennsylvania State University (College Station, PA) for plant tissue total analysis to determine the nutrient content of the biomass components. Determination of total $\mathrm{N}$ was done through the micro-Kjeldahl method, while the determination of $\mathrm{P}, \mathrm{K}, \mathrm{Ca}, \mathrm{Mg}$, and $\mathrm{S}$ was performed through the microwave acid digestion method and the inductively coupled plasma atomic emission spectrometry (ICP-AES).

\section{Statistical analyses}

The total biomass production $\left(\mathrm{Mg}_{\mathrm{dry}} \mathrm{ha}^{-1}\right)$ and annual yield $\left(\mathrm{Mg}_{\mathrm{dry}}\right.$ ha $\left.^{-1} \mathrm{y}^{-1}\right)$ of each treatment (defined as the mean of the yields of the three blocks divided by the rotation period), was calculated for each measurement plot. Nutrient removal $\left(\mathrm{kg} \mathrm{ha}^{-1} \mathrm{y}^{-1}\right)$ of each element for each treatment was calculated for each cultivar by multiplying the nutrient concentration for leaves, when present, and stem values by their yield. Mixed models were evaluated for a strip-strip factorial using the GLIMMIX procedure (SAS version 9.4) to estimate the effects of the six timing treatments $(T)$, cultivars $(C)$, and TxC interactions on total biomass production, annual yield, nutrient removal, and crop survival. Main factors and contrasts were tested at a critical level a of 0.05, interaction terms were tested at an a level of 0.15 [35]. Specific contrasts consisted of testing the early and late harvests of each cultivar, and individual cultivars like SX67 against the other three within a harvest date. Significance tests were conducted using the pairwise least square means (LS means) differences in the LSMEANS and Post Hoc analyses using the LSMESTIMATE statements [36, 37], although arithmetic means and standard errors are presented.

\section{Results And Discussion}

\section{Harvest timing and biomass removal}

Biomass yields for the site increased significantly from $35 \mathrm{Mg} \mathrm{ha}^{-1}$ to around $50 \mathrm{Mg} \mathrm{ha}^{-1}$ through the growing season (Table 3; Figure 2 top). In the 2007 harvest the mean annual increment through the growing season was between 7.3 and $10.6 \mathrm{Mg} \mathrm{ha}^{-1} \mathrm{y}^{-1}$, and jumped substantially in the second rotation to a range of 11.3 to $17.0 \mathrm{Mg} \mathrm{ha}^{-1} \mathrm{y}^{-1}$. This increase was consistent with results reported by Sleight et al [38], which showed that low first-rotations yields have a high propensity to increase in the second rotation. Leaf fall occurred following the October harvest. Late-rotation harvests (Oct-Apr) yielded a total of $7.87 \mathrm{Mg} \mathrm{ha}^{-1}$ more biomass than early-rotation harvests (Jun-Sep) $(P<0.0018)$. Mean foliar biomass within the 2007 harvest season was $3.42 \mathrm{Mg} \mathrm{ha}^{-1}$. There were no significant differences in foliar biomass 
through season beyond the total loss once leaves fell. The stem to foliage ratio increased slightly from 0.895 to $0.926(P<0.0001)$ between the Jun/Aug harvests and the Sep/Oct harvests.

Table 3

Summary of analyses of variance for the effects of treatment, cultivar, and $\mathrm{TxC}$ on biomass production following first rotation harvest timing treatments. Main effects significance tested at $\alpha=0.05$, while interaction significance was tested at $a=0.15$.

\begin{tabular}{|llll|}
\hline Biomass & Harvest Date (T) & Cultivar (C) & TxC \\
\cline { 2 - 4 } & & $p$-values & \\
\hline 2007 Stem & $<0.0001$ & 0.2375 & 0.4427 \\
\hline 2007 Foliage & 0.7452 & 0.0805 & 0.1105 \\
\hline 2007 Total & 0.0009 & 0.2224 & 0.4177 \\
\hline 2011 Annual Yield & $<0.0001$ & 0.3233 & 0.1488 \\
\hline Cumulative 2007-2011 & $\mathbf{0 . 0 1 4 2}$ & 0.2880 & 0.2657 \\
\hline DF & 5 & 3 & 9 \\
\hline
\end{tabular}

Post hoc pairwise analysis of observed TxC effects were evaluated. Increased biomass through the progression of harvests was driven by the cultivars 9870-40 and 9871-41 ( $P<0.0340)$ (Figure 2 bottom). However, there were no significant differences within the SX67 or 9882-25 cultivar harvests regardless of whether they occurred leaf-on or leaf-off $(P>0.48)$. Additionally, total biomass for the Jun/Aug harvest dates for SX67 were significantly higher than the other cultivars $(P=0.0415)$. The cultivars $9870-40,9871-$ 41 , and SX67 belong to the miyabeana species group, while $9882-25$ belongs to purpurea (Table 1).

\section{Harvest timing and second rotation regrowth}

The 2011 harvest (second rotation) represented four growing seasons of growth, plus any growth that occurred after the mid-season harvests during the summer/fall of 2007. Mean annual yield ranged in the second rotation ranged between 11.4 and $16.4 \mathrm{Mg} \mathrm{ha}^{-1} \mathrm{yr}^{-1}$ (Figure 3). Second rotation yield was $5.3 \mathrm{Mg}$ $\mathrm{ha}^{-1} \mathrm{yr}^{-1}$ more than the first rotation across all cultivars and times of harvest $(P<0.0001)$. Late-rotation harvests (Oct-Apr) produced $4.2 \mathrm{Mg} \mathrm{ha}^{-1} \mathrm{yr}^{-1}$ more biomass in the second rotation than areas where an early-rotation harvest took place (Jun-Sep) $(P<0.0001)$.

As with the 2007 harvest, there were only subtle post hoc effects detected in the 2011 harvests. As before, there was no significant difference in the SX67 performance related to harvest timing through 2011 $(P=0.3903)$, and SX67 plots harvested in Jun/Aug performed better in 2011 than any of the other cultivars $(P=0.0004)$ (Figure 3.3). The other three cultivars all had significant improvements in annual yield between the early (Jun-Sep) and late (Oct-Apr) seasons $(P<0.0065)$. 
It is already known that yield performance varies among willow cultivars (CITE). The differences in performance within the growing season is a unique result. What is particularly interesting is these results suggest that certain cultivars (i.e SX67) may be more resilient to the expanded harvest seasons that may be necessary to support large-scale commercial willow system. Regardless of when SX67 was harvested in the first rotation, second rotation yields were high and fairly consistent. Both high yield, and a tolerance for early-season harvesting may be a necessary selection criteria for cultivar deployments.

\section{Effect of harvest timing on first rotation nutrient removal}

During the 2007 harvests, the TxC interaction for the combined stem and foliage and for the stem nutrient removal was significant for all nutrients (Table 4). The TxC interaction for foliage was only significant for $\mathrm{K}$ and $\mathrm{Ca}$ but harvest date was significant for $\mathrm{N}, \mathrm{P}, \mathrm{K}$, and $\mathrm{Ca}$. While foliage had 3-10 times the concentration compared to stemwood, nutrient removals were highest for the woody component due to quantity. 
Table 4

Summary of analyses of variance for the effects of treatment, cultivar, and TxC on total nutrient removal (stem+foliage) on the first rotation harvest. Main effects significance tested at $a=0.05$, while interaction significance was tested at $a=0.15$.

\begin{tabular}{|c|c|c|c|}
\hline \multirow[t]{2}{*}{ Element } & Harvest Date $(\mathrm{T})$ & Cultivar (C) & TxC \\
\hline & \multicolumn{3}{|c|}{ p-values } \\
\hline \multicolumn{4}{|c|}{ Combined Stem and Foliage } \\
\hline$N\left(\mathrm{~kg} \mathrm{ha}^{-1} \mathrm{y}^{-1}\right)$ & 0.0324 & 0.0752 & 0.0259 \\
\hline$P\left(\mathrm{~kg} \mathrm{ha}^{-1} \mathrm{y}^{-1}\right)$ & 0.0616 & 0.0969 & 0.0940 \\
\hline $\mathrm{K}\left(\mathrm{kg} \mathrm{ha}^{-1} \mathrm{y}^{-1}\right)$ & 0.0002 & 0.0459 & 0.1097 \\
\hline $\mathrm{Ca}\left(\mathrm{kg} \mathrm{ha}^{-1} \mathrm{y}^{-1}\right)$ & 0.0128 & 0.0024 & 0.0101 \\
\hline $\operatorname{Mg}\left(\mathrm{kg} \mathrm{ha}^{-1} \mathrm{y}^{-1}\right)$ & 0.0071 & 0.0107 & 0.0152 \\
\hline$S\left(\mathrm{~kg} \mathrm{ha}^{-1} \mathrm{y}^{-1}\right)$ & 0.0032 & 0.0384 & 0.0227 \\
\hline \multicolumn{4}{|l|}{ Stem } \\
\hline$N\left(k g h a^{-1} y^{-1}\right)$ & $<0.0001$ & 0.0737 & 0.0065 \\
\hline$P\left(\mathrm{~kg} \mathrm{ha}^{-1} \mathrm{y}^{-1}\right)$ & 0.0131 & 0.0809 & 0.0436 \\
\hline$K\left(\mathrm{~kg} \mathrm{ha}^{-1} \mathrm{y}^{-1}\right)$ & 0.0718 & 0.0441 & 0.1396 \\
\hline $\mathrm{Ca}\left(\mathrm{kg} \mathrm{ha}^{-1} \mathrm{y}^{-1}\right)$ & 0.0062 & 0.0019 & 0.0043 \\
\hline $\operatorname{Mg}\left(\mathrm{kg} \mathrm{ha}^{-1} \mathrm{y}^{-1}\right)$ & $<0.0001$ & 0.0012 & 0.0011 \\
\hline$S\left(k g h a^{-1} y^{-1}\right)$ & 0.0006 & 0.0492 & 0.0025 \\
\hline \multicolumn{4}{|l|}{ Foliage } \\
\hline$N\left(\mathrm{~kg} \mathrm{ha}^{-1} \mathrm{y}^{-1}\right)$ & 0.0010 & 0.0708 & 0.1902 \\
\hline$P\left(\mathrm{~kg} \mathrm{ha}^{-1} \mathrm{y}^{-1}\right)$ & $<0.0001$ & 0.0989 & 0.2609 \\
\hline$K\left(k g h a^{-1} y^{-1}\right)$ & 0.0014 & 0.0264 & 0.1422 \\
\hline $\mathrm{Ca}\left(\mathrm{kg} \mathrm{ha}^{-1} \mathrm{y}^{-1}\right)$ & 0.0086 & 0.0078 & 0.0827 \\
\hline $\operatorname{Mg}\left(\mathrm{kg} \mathrm{ha}^{-1} \mathrm{y}^{-1}\right)$ & 0.3518 & 0.0991 & 0.2116 \\
\hline$S\left(\mathrm{~kg} \mathrm{ha}^{-1} \mathrm{y}^{-1}\right)$ & 0.7788 & 0.0461 & 0.3205 \\
\hline
\end{tabular}




\begin{tabular}{|llll|}
\hline Element & Harvest Date (T) & Cultivar (C) & TxC \\
\cline { 2 - 4 } & & $p$-values \\
\hline DF & 5 & 3 & 9 \\
\hline
\end{tabular}

\section{Nitrogen}

Nitrogen is generally one of the most limiting nutrients for most crops [11, 39]. Nitrogen was most affected by season, but there were significant TxC interactions detected (Table 4, Figure 4). Significant effects of harvest date, cultivar, and TxC were observed on total $\mathrm{N}$ removal, with the highest removal observed by cultivar SX67 in Jan (110 kg N ha-1 $\mathrm{y}^{-1}$ ) and the lowest by $9870-40$ in Jan (46 kg N ha-1 $\mathrm{y}^{-1}$ ). Removals by cultivar SX67 were significantly higher than the removals of all the other cultivars in Jan and statistically similar to cultivar 9870-40 in Jun and Aug. On the other hand, removals in Sep, Oct, and Apr were statistically similar for all cultivars. Overall, total $\mathrm{N}$ removal was lower in $\mathrm{Apr}\left(57 \mathrm{~kg} \mathrm{~N} \mathrm{ha}^{-1}\right.$ $\left.\mathrm{y}^{-1}\right)$ compared to Oct $\left(78 \mathrm{~kg} \mathrm{~N} \mathrm{ha}^{-1} \mathrm{y}^{-1}\right)$ and Jan $\left(73 \mathrm{~kg} \mathrm{~N} \mathrm{ha}^{-1} \mathrm{y}^{-1}\right)$. Total $\mathrm{N}$ removal for the other treatments was not significantly different. When just considering woody biomass, the lowest removal was in Jun (44 kg N ha $\left.{ }^{-1} \mathrm{y}^{-1}\right)$, Aug (45 kg N ha-1 $\left.\mathrm{y}^{-1}\right)$, and Sep $\left(46 \mathrm{~kg} \mathrm{~N} \mathrm{ha}^{-1} \mathrm{y}^{-1}\right)$.

Observing the response of individual cultivars, $\mathrm{N}$ removal is proportional to biomass removal for harvests occurring on a particular date (Figures 2 and 4). Although there was not a significant cultivar effect $(P=0.0752)$, the mean removal for cultivars ranged from 57.7 to $83.9 \mathrm{~kg} \mathrm{~N} \mathrm{ha}^{-1} \mathrm{y}^{-1}$. As the growing season progresses into September, $\mathrm{N}$ removal decreases relative to biomass removal. As the trees harden for winter, there is a spike in nitrogen removal in October, and with the signal diminishing again as the dormant season progresses. Post hoc analysis indicates there was no significant differences in total $\mathrm{N}$ removal for the early Jul-Sep harvests compared to the later Oct-Apr harvests $(P=0.0805)$, although the amount of $\mathrm{N}$ removed in the woody biomass in the early season harvest was over $20 \mathrm{~kg} \mathrm{ha}^{-1} \mathrm{y}^{-1}$ lower $(p<0.0001)$. In this hand harvested trial the vast majority of the leaves were removed and included in both the biomass and nutrient calculations. However, in large-scale harvests using single pass cut and chip harvesting systems only a portion of the foliage is removed from the field. Some of the leaves are lost when the stems are dragged through the canopy of plants in front of them and fed into the harvester. Observation over hundreds of hectares of large scale harvesting [24] indicates that more foliage is lost when harvests occur in the fall. The other place in the system where foliage is returned to the site is when material is blown from harvester into wagons or other collection vehicles. Foliage is less dense than the woody material from the rest of the plant and a portion of it visibly separates from the stream of biomass being blown into the wagon and drops on the ground. In addition to foliage studies show that 7 to $15 \%$ of the standing biomass in willow fields can be left behind during mechanical harvesting operations $[19,21$, 40]. There is a lack of good data on the proportion of foliage returned to the site during mechanical harvesting, but it does impact nutrient dynamics in these systems and needs to be considered. The handharvested data in this trial is some of the only data of its kind for trials in the region, but will represent more removal than occurs 
There was a significant difference in $\mathrm{N}$ removal for SX67 compared to the other cultivars due to total biomass ( $P=0.0022)$, but the change was not significant for $\mathrm{N}$ removal over the course of the treatments $(P=0.4629)$. $S X 76$ has stem and foliar $N$ concentrations at the low end of the range among willow cultivars that have been tested (Tharakan et al. 2004) but yields in this trial were consistently high across all the harvest dates, emphasizing the importance that total biomass removal has on nutrient removal. It is important to note that there are differences in the timing of leaf drop among cultivars [41,42], and that this will influence the mount of nutrient removed during harvesting both in terms of biomass and the nutrient concentration of the remaining foliage.

\section{Phosphorus}

The combined pattern for $\mathrm{P}$ was congruent with $\mathrm{N}$ in that $\mathrm{P}$ removal was proportional overall to biomass removal, but in the case of $P$, the combined removal was not significant relative to harvest timing. Both the harvest timing and cultivar main effects were not significant; the range of means among cultivars was 7.7 to $11.6 \mathrm{~kg} \mathrm{P} \mathrm{ha}^{-1} \mathrm{y}^{-1}$. Some TxC effects were significant and harvest timing was significant for the stem and foliage individually (Table 4, Figure 5). Post hoc analyses indicate total $P$ removals in the early growing season by SX67 were $4.7 \mathrm{~kg} \mathrm{P} \mathrm{ha}^{-1} \mathrm{y}^{-1}$ higher than other cultivars $(P=0.0025)$, and there was $2.8 \mathrm{~kg} \mathrm{Pha}^{-1} \mathrm{y}^{-1}$ more $\mathrm{P}$ removed in SX67 in the early growing season compared to late and dormant harvests $(P=0.0275)$. The general pattern is that $P$ removal increased as the crop reached the dormancy stage (from Jun to Oct-Jan), and dropped again in Apr to similar levels observed in Jun, Aug, and Sep; while removals via foliage biomass reduced significantly as the plants started to shed their leaves (Figure 5). While there are differences in the patterns of $P$ removal in wood and foliage, the total amounts removed are relatively small ( $\left.7-14 \mathrm{~kg} \mathrm{P} \mathrm{ha}^{-1} \mathrm{yr}^{-1}\right)$ and in the northeast U.S. where this trial occurred many of the soils have more than adequate or excessive amount of $\mathrm{P}$ due to the inherent characteristics of this soils and management, especially additions of manure and P fertilizers [43]. In other regions or on disturbed sites with lower soil $\mathrm{P}$ levels the removal patterns seen here need to be considered in nutrient management decisions.

\section{Potassium}

Potassium, along with $\mathrm{Ca}^{2+}$, is the most abundant inorganic chemicals in plant cellular media and is the second most abundant nutrient in leaf tissues after $\mathrm{N}$. Potassium plays important roles in the development and functioning of plants. Potassium is mobile in plant tissues and organs and it cycles rapidly among plant parts [44], The total removal of $\mathrm{K}$ was significantly affected by harvest date, cultivar, and TxC (Table 3.4). Potassium removal decreased from by a high of $52 \mathrm{~kg} \mathrm{~K} \mathrm{ha}^{-1} \mathrm{yr}^{-1}$ in Jun/Aug to approximately $30 \mathrm{~kg} \mathrm{~K} \mathrm{ha}^{-1} \mathrm{yr}^{-1}$ by the following April (Figure 6). The TxC interaction showed significantly higher removals by cultivars $9870-40$ and SX67 for Jun (54.1 kg K ha $\mathrm{k}^{-1} \mathrm{y}^{-1}$ for $9870-40$ and $67.8 \mathrm{~kg} \mathrm{~K} \mathrm{ha}^{-1} \mathrm{y}^{-1}$ for SX67) and Aug (64.0 kg K ha ${ }^{-1} \mathrm{y}^{-1}$ for $9870-40$ and $63.7 \mathrm{~kg} \mathrm{~K} \mathrm{ha}^{-1} \mathrm{y}^{-1}$ for SX67), significantly higher removal by $9870-40$ in Oct $\left(63.2 \mathrm{~kg} \mathrm{~K} \mathrm{ha}^{-1} \mathrm{y}^{-1}\right)$, and significantly higher removal by SX67 in Jan (52.9 $\mathrm{kg} \mathrm{K} \mathrm{ha}^{-1} \mathrm{y}^{-1}$ ) (Figure 6). In contrast to the results of $\mathrm{N}$ and $\mathrm{P}$, the removal of $\mathrm{K}$ via woody biomass was higher during the full-leaf out stages of the crop ( $40.0 \mathrm{~kg} \mathrm{~K} \mathrm{ha}^{-1} \mathrm{y}-1$ in Jun and 42.6 
$\mathrm{kg} \mathrm{K} \mathrm{ha}^{-1} \mathrm{y}^{-1}$ in Aug), compared to the late season harvests (Sep, Oct, Jan, and Apr). Similarly, K removals via foliage were higher in early season (11.3 $\mathrm{kg} \mathrm{K} \mathrm{ha}^{-1} \mathrm{y}^{-1}$ in Jun) and decreased as the crop approached the dormancy stage. Fromm (2010) observed seasonal variation in the $\mathrm{K}^{+}$concentrations in poplar cambium with high levels in the spring and lower levels in the fall and winter season.

\section{Calcium}

Significant effects of harvest date, cultivar, and TxC were observed in total removals of $\mathrm{Ca}$ (Table 4). Across all cultivars total Ca removals were higher in Aug (152.2 kg Ca ha-1 $\left.\mathrm{y}^{-1}\right)$, Oct (164.6 kg Ca ha-1 $\left.\mathrm{y}^{-1}\right)$ and Jan (153.5 kg Ca ha $\left.{ }^{-1} \mathrm{y}^{-1}\right)$ than in Jun (126.2 $\left.\mathrm{kg} \mathrm{ca} \mathrm{ha}^{-1} \mathrm{y}^{-1}\right)$ and April (121.0 kg Ca ha-1 $\left.\mathrm{y}^{-1}\right)$. The TxC interaction showed that cultivars 9870-40, SX67, and 9871-41 removed significantly higher amount of $\mathrm{Ca}$ in all harvests compared to cultivar 9882-25 (Figure 7), but that the cultivar with the highest removal varied. Cultivar SX67 had the highest removals in Jun (173.9 $\left.\mathrm{kg} \mathrm{Ca} \mathrm{ha}^{-1} \mathrm{y}^{-1}\right)$, Aug $(193.2 \mathrm{~kg} \mathrm{Ca}$ $\left.\mathrm{ha}^{-1} \mathrm{y}^{-1}\right)$ and Jan (230.3 $\left.\mathrm{kg} \mathrm{Ca} \mathrm{ha}^{-1} \mathrm{y}^{-1}\right)$ while 9870-40 had the highest removal in Oct (231.4 kg Ca ha-1 $\left.\mathrm{y}^{-1}\right)$. Among cultivars, SX67 removed higher total $\mathrm{Ca}\left(173.1 \mathrm{~kg} \mathrm{Ca} \mathrm{ha}^{-1} \mathrm{y}^{-1}\right)$ and $9882-25$ removed significantly less $\left(77.3 \mathrm{~kg} \mathrm{Ca} \mathrm{ha}^{-1} \mathrm{y}^{-1}\right)$. Stem only Ca removals were lower in Jun (112.3 kg Ca ha $\mathrm{y}^{-1}$ ) and Sep (115.1 kg Ca ha-1 $\left.\mathrm{y}^{-1}\right)$ and higher in Jan (153.5 kg Ca ha-1 $\left.\mathrm{y}^{-1}\right)$, showing an increasing pattern from early season harvests (Jun, Aug, Sep) to late season harvests (Oct and Jan) until a decrease in Apr. Foliage only Ca removals were significantly lower in Jun (13.9 kg Ca ha- $\left.\mathrm{y}^{-1}\right)$ compared to the other harvests, and increased slightly as the crop approached the dormancy stage (Figure 7), which is different than observations for foliar removals of $\mathrm{N}, \mathrm{P}$, and $\mathrm{K}$. Calcium is generally not a limiting nutrient, but can be important in scenarios such as post-pasture secondary succession [44].

\section{Magnesium}

Calcium and magnesium frequently mirror each other as secondary nutrients. Total removals of $\mathrm{Mg}$ was also significantly affected by harvest date, cultivar, and TxC (Table 4). Mean removals within harvest dates ranged between 7.1 and $10.1 \mathrm{~kg} \mathrm{Mg} \mathrm{ha}^{-1} \mathrm{yr}^{-1}$. While Mg has similar overall patterns to Ca (Figure 8), foliar content constituted a much higher proportion of the total removal. No significant differences were observed among cultivars in treatments at in the late growing season (Aug-Oct). The cultivar SX67 was associated with significantly more $\mathrm{Mg}$ removed in Jun $\left(10.1 \mathrm{~kg} \mathrm{Mg} \mathrm{ha}^{-1} \mathrm{y}^{-1}\right)$ and $\operatorname{Jan}(12.2 \mathrm{~kg} \mathrm{Mg}$ $\left.\mathrm{ha}^{-1} \mathrm{y}^{-1}\right)$, while cultivar 9882-25 had the highest removal in Apr (10.8 $\mathrm{kg} \mathrm{Mg} \mathrm{ha}^{-1} \mathrm{y}^{-1}$ ) (Figure 8). A significant harvest date effect showed that total removals of Mg were lower in $\operatorname{Apr}\left(7.1 \mathrm{~kg} \mathrm{Mg} \mathrm{ha}^{-1} \mathrm{y}^{-1}\right)$ and Jun (7.9 kg Mg ha $\left.{ }^{-1} \mathrm{y}^{-1}\right)$ and higher in Oct (10.4 $\left.\mathrm{kg} \mathrm{Mg} \mathrm{ha}^{-1} \mathrm{y}^{-1}\right)$ and August (9.6 kg Mg ha-1 $\left.\mathrm{y}^{-1}\right)$. Stem only removal of $\mathrm{Mg}$ showed an increasing pattern until the crop reached the dormancy stage followed by a decrease in Apr (Figure 8), with the lowest removal occurring in Jun (5.1 kg Mg ha-1 $\mathrm{y}^{-1}$ ) and the highest in Jan $\left(8.5 \mathrm{~kg} \mathrm{Mg} \mathrm{ha}^{-1} \mathrm{y}^{-1}\right)$. Foliar only $\mathrm{Mg}$ removal, did not show differences among harvest dates (Figure 3.8), but resulted higher in Aug (3.2 $\left.\mathrm{kg} \mathrm{Mg} \mathrm{ha}^{-1} \mathrm{y}^{-1}\right)$ and lower in Oct ( $2.5 \mathrm{~kg} \mathrm{Mg}$ $\left.\mathrm{ha}^{-1} \mathrm{y}^{-1}\right)$.

\section{Sulfur}


Significant effects for harvest date, cultivar, and TxC were observed in the total removal of S (Table 4). Sulfur removal ranged from 5.6 to $9.0 \mathrm{~kg} \mathrm{~S} \mathrm{ha}^{-1} \mathrm{yr}^{-1}$ relative to timing, with the maximum reached at the end of the growing season, and the minimum at the end of the dormant season (Figure 9). A relatively high proportion of the nutrient was associated with foliage removal, but there were no significant differences in foliar removal among dates. The primary difference in harvest timing was at the immediate end of the growing season where cultivar SX67 had the highest removal in Jun $\left(11.1 \mathrm{~kg} \mathrm{~S} \mathrm{ha}^{-1} \mathrm{y}^{-1}\right)$, Aug, and Jan (10.8 kg S ha-1 $\left.\mathrm{y}^{-1}\right)$, while cultivar 9870-40 had the highest removal in Oct (12.4 kg S ha-1 $\left.\mathrm{y}^{-1}\right)$ (Figure 9).

\section{Implications of early harvests on biomass production and regrowth}

One of the concerns with growing season harvests is that willow aggressively produces coppice regrowth after cutting. After cutting, the plant uses energy reserves to produce shoots that may not harden sufficiently for winter; that growth dies back and the plant has to produce these shoots again the following growing season. Mean combined biomass production for the 2007 and 2011 harvests ranged from approximately $80 \mathrm{Mg} \mathrm{ha}^{-1}$ for harvests that were timed in Jun/Aug, to over $100 \mathrm{Mg} \mathrm{ha}^{-1}$ for harvests timed in April (Figure 10); harvest timing was the only significant effect (Table 3). On closer inspection, despite a substantial increase in biomass production in the second rotation compared to the first rotation the loss in production and subsequent reduction in revenue may be considerable for early rotation harvests. Also, the September timing had first rotation harvest yields comparable to the dormant seasons, but had the poorest second rotation yields, which suggests carbohydrates were expended on new growth that was unable to harden and survive through the winter.

Harvest timing had a significant impact on both the total biomass production over two rotations and second rotation yield. This study suggests that harvesting during the growing season negatively impacts biomass production and yield compared to dormant season harvests. However, second rotation biomass total production was significantly higher than first rotation production for harvests in Jun and Aug. In a comprehensive study comparing first- and second-rotation yields, there was a propensity for second rotation yields in dormant harvests to increase relative to the first rotation for a number of shrub willow cultivars across a range of sites [38]. In this study, the mean first rotation yields in midsummer 2007 were 7.3 $\mathrm{Mg} \mathrm{ha}^{-1} \mathrm{y}^{-1}$ in Jun and 7.6 Mg ha-1 $\mathrm{y}^{-1}$ in Aug, and increased to 13.1 and $13.2 \mathrm{ha}^{-1} \mathrm{y}^{-1}$ respectively by the second rotation. On the other hand, harvests in Sep, Oct, Jan, and Apr did not present significant changes up or down for the second rotation; however, they did show significant increases in their yield, given the shorter length of the second rotation ( 4 years) compared to the first ( $\sim 5$ years). Sleight et al. [38] reported that when first rotation yield is between 9.4-12.9 $\mathrm{Mg} \mathrm{ha}^{-1} \mathrm{y}^{-1}$, the probability of increasing yield in the second rotation is $<50 \%$. First rotation yields in the current study for Sep, Oct, Jan, and Apr ranged from $9.5-10.6 \mathrm{Mg} \mathrm{ha}^{-1} \mathrm{y}^{-1}$. Second rotation yields in our study increased by $78 \%$ for Jun and Aug, $28 \%$ for Sep, $52 \%$ for Oct, $87 \%$ for Jan, and $43 \%$ for Apr. Still, despite significant increases, the willow harvested during the growing season (Jun, Aug, and Sep) did not match the yields obtained by the plants 
harvested during the dormant season (Oct, Jan, and Apr), even though they had the equivalent of an extra growing season (in growing degree days [GDD]; Table 2), in comparison to dormant season harvests.

The effects of harvest timing on shrub willow, and other coppice species, growth have been studied [26$30,45]$; despite this, gaps in understanding the impact of harvesting season on the plants' growth remain. Certain commonalities exist among previous results; lower plant growth and development were observed when harvested during the growing season. The uncertainties about the harvest season effect are attributed to a variety of reasons: e.g. (1) possible lower root carbohydrate reserves when harvesting during summer, (2) frost damage of newly regenerated and immature shoots harvested late in the growing season, or (3) a limited nitrogen reserve supply for regrowth [26, 30,46]. Our results showed similar growth response to previous studies. However, we cannot confirm any of these previous attributions. Woody nitrogen concentration in this study showed a significant increase from the growing season (3.3 to $3.5 \mathrm{mg} \mathrm{kg}^{-1}$ ) until the dormancy season ( 4.1 to $4.5 \mathrm{mg} \mathrm{kg}^{-1}$ ), with a significant decrease in early spring (3.4 $\left.\mathrm{mg} \mathrm{kg}^{-1}\right)$, during bud burst [21], similarly to the observations made by other studies [46, 47]. Although we did not study the dynamics and translocation of nitrogen, carbohydrates or other compounds in the plant, or evaluate the plants for frost damage, significant reductions and increases in leaf and woody nitrogen were observed as the plants approached the dormancy stage. Nonetheless, the reduced nutrient reserves observed during the growing season harvests (Jun, Aug, and Sep) is a plausible reason for the effect of harvest date on biomass production and yield.

A caveat to the biomass concerns are that these plots were hand harvested. When SRWC are mechanically harvested, machines generally leave some proportion of material behind. Berhongaray et al [22] reported that poor efficiency can result in almost a quarter of the material being left behind; however that study relied on an exceptionally small sample areas. Eisenbies et al. [40] found a range between 6 and 8 percent for leaf-off harvests, however, it was on a limited number of plots. In some follow up work a more extensive set of data from harvests during the growing season suggests that the amount of dropped material is under $<9 \%$ of the harvestable biomass for $90 \%$ of the harvested area, $<23 \%$ for $5 \%$ of the area, and $<35 \%$ for $4 \%$ [19]. One percent or less of the area can have exceptionally high quantities of dropped material due to spillage of chips from the wagon or spout. However, harvesting systems are still under development and experience among operators is increasing so the percentage of dropped material has the potential to be reduced in the future. Another issue with growing season harvests is that foliage is not a desirable component for many end users [24, 48, 49]; Future harvesting systems may incorporate wood/foliage separation in order to improve feedstock quality, especially if it improves feedstock grade, price, or offsets costs.

The results from the TxC interaction for total biomass production were highly influenced by the higher performance of cultivar SX-67 (Figure 2 and 3). It appeared to have high biomass production potential over both rotations regardless of harvest timing. Additionally, cultivar 9882-25 did not show a strong response to harvest timing, but had relatively low total biomass production. Meanwhile, cultivars 9870-40 and 9871-41 both displayed a clearer harvest timing effect. These two distinct cultivar groups suggest, along with potential yield, that certain cultivars may be tolerant of an expanded harvesting season, while 
other cultivars are sensitive to growing season harvests. This result deserves further study in the future as climate changes and the opportunities for dormant season only harvests decline in the region.

\section{Implications of early harvests on nutrient removal}

The concerns over short rotations and frequent harvests of shrub willow principally relate to the quantity of nutrients removed, the potential impact on soil nutrient content, and the long-term productivity of the crop. Although this issue has been studied for dormant season harvests [50-53], the study of how timing of harvest affects nutrient removal has been limited, with most of the research performed on nutrient concentration, allocation, and translocation in the shrub willow biomass [46, 47, 54-56]. Our results indicate there are potential effects of harvest date on total removals (stem and foliage) of $\mathrm{N}, \mathrm{K}, \mathrm{Ca}, \mathrm{Mg}$, and $S$, which may be relevant to decisions on harvest timing. Plants harvested in Oct had the highest N, P, $\mathrm{Ca}, \mathrm{Mg}$, and $\mathrm{S}$ removals, while $\mathrm{K}$ removals higher in Jun and Aug. During the growing season, a high proportion of the nutrients are located in the foliage tissue; when the foliage starts to shed, a portion of these nutrients are translocated into the shoots and root system [47, 54] (Figures 4-9), which explains the higher removals observed during Oct and Jan, when limited to no foliage is present and most of the nutrients are concentrated in the shoots. During spring (Apr), the nutrients are translocated into growing parts (tips of twigs and branches) to support leaf production and branch growth, but given the lower proportion of tips compared to stem biomass, the higher concentration present in the tips are diluted and shadowed by the lower concentration in the stem biomass.

Nutrient removal was impacted by the interaction of the timing of the harvest and the different cultivars in this trial, which has potentially interesting implications for the deployment and management of willow crops. Among the cultivars studied, SX67 resulted in consistent high total biomass and annual yield, but with some nutrients had comparatively high nutrient removal across the harvest dates. Fabio et al., 2017 [57], studied the contributions of genotype and environment on shrub willow biomass composition, observing high influence of environment as well as genotype*environment interaction in yield, and concluded that the selection of genotypes and growing environment could be implemented to increase biomass production. Their results can help explain the significant differences observed between SX67 and the other cultivars in our study, where environmental conditions could have been favorable for SX67 growth, compared to the other cultivars and regardless of the harvest date. Fabio et al. [57] also found two SX cultivars (SX61 and SX64), which belongs to the same diversity group as SX67 (Table 3.1), to be stable and high yielding across a range of environmental conditions.

Alternatively, the cultivars $9870-40$ and 9871-41, which had had comparable biomass production to SX67 from the September harvest on (Figure 2), also appeared to have comparatively lower nutrient removal (Figures 4-9). When biomass yield was added as a covariate to the analysis of total nutrient removal, this trend was statistically significant for the LS means for N, P, K, Mg, and S (Table 5). For the macronutrients, 9870-40 and 9871-41 had approximately $10 \mathrm{~kg} \mathrm{ha}^{-1} \mathrm{yr}^{-1}$ and $2.5 \mathrm{~kg} \mathrm{ha}^{-1} \mathrm{yr}^{-1}$ lower exports for $\mathrm{N}$ and $\mathrm{P}$ respectively; the difference for $\mathrm{K}$ only applied to cultivar $9871-41$. While the cultivar SX67 was shown to be resilient to an expanded harvesting window in terms of biomass production. This result suggests that cultivar selection could also consider nutrient removal relative to harvest yield as selection 
criteria. As mentioned previously, if technology were introduced that separated wood and foliage during harvesting and redistributed this material on site, that could offset some removal, but the differences between cultivars in terms of foliage is not as notable.

Table 5

LS means for nutrient removal for each cultivar across all harvest dates in 2007 for analysis that included 2007 yield as a covariate $(P<0.0001)$. $P$ value for the cultivar component of the model is provided. Letters indicates indicate significant differences in LS means between cultivars for each nutrient.

\begin{tabular}{|c|c|c|c|c|c|c|}
\hline \multirow[t]{2}{*}{ Cultivar } & \multicolumn{6}{|l|}{ Nutrient } \\
\hline & $\mathrm{N}$ & $P$ & K & $\mathrm{Ca}$ & $\mathrm{Mg}$ & $S$ \\
\hline & \multicolumn{6}{|c|}{ kg ha-1 yr-1 } \\
\hline $9882-25$ & $69.8 \mathrm{AB}$ & $11.7 \mathrm{~A}$ & $48.3 \mathrm{~A}$ & $97.9 \mathrm{~B}$ & $10.8 \mathrm{~A}$ & 7.7 AB \\
\hline $9870-40$ & $58.7 \mathrm{BC}$ & $8.4 \mathrm{~B}$ & $45.8 \mathrm{~A}$ & $148.4 \mathrm{~A}$ & $7.2 \mathrm{~B}$ & $7.2 \mathrm{BC}$ \\
\hline $9871-41$ & $56.4 \mathrm{C}$ & $7.6 \mathrm{~B}$ & $31.0 \mathrm{~B}$ & $157.6 \mathrm{~A}$ & $7.3 \mathrm{~B}$ & $6.1 \mathrm{C}$ \\
\hline SX67 & $78.2 \mathrm{~A}$ & $10.8 \mathrm{~A}$ & $46.4 \mathrm{~A}$ & $161.8 \mathrm{~A}$ & $9.2 \mathrm{~A}$ & $8.8 \mathrm{~A}$ \\
\hline$P$ value & 0.0046 & 0.0028 & 0.0013 & 0.0050 & 0.0025 & 0.0047 \\
\hline
\end{tabular}

Considering harvest date effects on biomass production and nutrient removal the selection and deployment of different cultivars could be decided depending on site conditions and characteristics; however, this is based on a set of four cultivars and one site only. Cultivar SX67 would be a strong candidate to be deployed in sites where leaf-on harvests might be required for some portion of the life of the crop, ensuring high yield in the following rotation; however, SX67 also showed a variable and high nutrient removal across harvest dates. Hence, deploying a combination of SX67 and 9871-41 (which resulted in variable yielding and low and variable nutrient removal across the harvest dates) could be beneficial both for the overall yield and nutrient removal rates on the site. Assuming harvests to occur from Aug to Oct (as observed in commercial sites in NY given poor site conditions in fall and winter seasons) we could assume mean yield of $13.8 \mathrm{Mg} \mathrm{ha}^{-1} \mathrm{y}^{-1}$ and removals of $69.7 \mathrm{~kg} \mathrm{~N} \mathrm{ha}^{-1} \mathrm{y}^{-1}, 9.9 \mathrm{~kg} \mathrm{P}$ $\mathrm{ha}^{-1} \mathrm{y}^{-1}, 42.4 \mathrm{~kg} \mathrm{~K} \mathrm{ha}^{-1} \mathrm{y}^{-1}, 170.4 \mathrm{~kg} \mathrm{Ca} \mathrm{ha}^{-1} \mathrm{y}-1,9.2 \mathrm{~kg} \mathrm{Mg} \mathrm{ha}^{-1} \mathrm{y}^{-1}$, and $8.3 \mathrm{~kg} \mathrm{~S} \mathrm{ha}^{-1} \mathrm{y}^{-1}$. In contrast, a deployment of cultivars with characteristics similar to SX67 only, will ensure higher yields $\left(15.5 \mathrm{Mg} \mathrm{ha}^{-1}\right.$ $\left.\mathrm{y}^{-1}\right)$, but will likely result in higher nutrient removal rates $\left(80.5 \mathrm{~kg} \mathrm{~N} \mathrm{ha}^{-1} \mathrm{y}^{-1}, 12.0 \mathrm{~kg} \mathrm{P} \mathrm{ha}^{-1} \mathrm{y}^{-1}, 51.3 \mathrm{~kg} \mathrm{~K}\right.$ $\mathrm{ha}^{-1} \mathrm{y}^{-1}, 174.7 \mathrm{~kg} \mathrm{Ca} \mathrm{ha}^{-1} \mathrm{y}^{-1}, 10.0 \mathrm{~kg} \mathrm{Mg} \mathrm{ha}^{-1} \mathrm{y}^{-1}$, and $\left.10.0 \mathrm{~kg} \mathrm{~S} \mathrm{ha}^{-1} \mathrm{y}^{-1}\right)$.

A careful selection of cultivar and growing environment, as explained by Fabio et al. [57], could ensure higher yields over rotations, as well as similar results when harvesting in different dates and seasons of the year. Hence, by considering cultivars with lower variation both in yield and nutrient removal, a wider harvesting window could be supported, ensuring the biomass production of subsequent rotations and facilitating the nutrient management practices. However, a wider array of cultivars and sites should be 
explored to confirm the patterns observed, since a limited suite of cultivars and only one site were used at this study.

\section{Implications of harvest dates for commercial operations}

This study indicates that harvesting during the plant's dormancy stage (late fall, winter, and early spring) will promote higher biomass production with less nutrient export from the site via harvested biomass. Best practices for shrub willow management had already recommended for many years that harvesting during winter months, after leaf fall has already occurred [23], in part, based on studies indicating higher biomass production and shrub willow growth when the harvest is performed during the plant's dormancy stage [26, 28-30]. However, commercial shrub willow harvest operations in NY are being extended into the mid-late growing season because following best practices has proven challenging due to weather and ground conditions on large sites. Future expansion of biorefineries that require year round supply of biomass may also prompt an expansion of the harvesting window because of the dry matter loss associated with willow that is stored for three to six months depending on the time of harvest. The tradeoff between differences in yield with more frequent harvests over the entire years and losses in both quality and quality of biomass that is stored for longer periods of time for dormant season only harvests needs to be assessed and incorporated into analysis that includes different conversion processes and end products.

Shrub willow crops are commonly planted on marginal agricultural land in NYS [6]. The term "marginal land" has different meanings in various settings, but here refers to land at the margins of profit, where potential economic returns are at a breakeven point with production costs [58], which was recently characterized as socially marginal land when externalities are included [59]. These lands generally have use restrictions, caused by slope, elevation, depth, soil texture, internal drainage, fertility, and/or remoteness. In the northeast US a common limitation for this land are most often related to hydrology, which results in seasonal saturation or near saturation [6]. Hence, it has been observed that the operation of heavy machinery on these lands during wintertime requires frozen ground. If snowfalls come before the ground freezes can support heavy equipment, access to the site may be hindered for the entire season, or operating costs become prohibitive.

According to this study, harvesting during August will result in significantly lower total biomass production and yield compared to fall or winter harvests. Total biomass production for the Aug harvest date resulted in $77.5 \mathrm{Mg} \mathrm{ha}^{-1}$, while in Oct the total biomass production was $94.3 \mathrm{Mg} \mathrm{ha}^{-1}$. Considering a wet biomass price at plant gate of $\$ 30.5 \mathrm{Mg}^{-1}$ [60], we could estimate a gross revenue of $\$ 4,584.2 \mathrm{ha}^{-1}$ after two rotations if harvesting during Aug and $\$ 5,236.9 \mathrm{ha}^{-1}$ if harvested during Oct (Table 6). Still, if the results of this research are considered, and the harvest is performed during Apr, it would result in a total of $\$ 5,731 \mathrm{ha}^{-1}$ after two rotations. These results however, do not consider other costs or incomes in the system, only the economic return generated by selling the biomass. As already mentioned harvesting during rainy or snowy periods could increase the harvesting costs, add delays to harvesting with small amounts of rainfall because evapotranspiration is so low during the dormant season, or prohibit the 
harvest from happening altogether. In addition to differences in biomass production recent analysis of willow harvests has shown that throughput from leaf-on harvests on dry ground conditions $(29.7 \mathrm{Mg}$ $\mathrm{hr}^{-1}$ ) are $59 \%$ lower than leaf off harvests on dry ground $\left(71.8 \mathrm{Mg} \mathrm{hr}^{-1}\right)$. This will increase harvesting costs and reduce the profitability of leaf-on harvests [61]. While leaf off harvest throughput in wet conditions (42.4 $\mathrm{Mg} \mathrm{hr}^{-1}$ ) was $41 \%$ lower than when in dry conditions. Despite higher biomass production and gross return generated in Apr, spring snow melt could contribute to soil water saturation, resulting in site conditions not ideal for operating harvesting equipment and increasing harvesting costs, which could lead to lower net revenue compared to other months, when harvesting conditions are ideal. The tradeoffs between losses in production and the increases costs associated with trying to harvest on these poorly drained sites during the dormant season is another factor that needs to be incorporated into decisions about timing of harvesting operations.

Table 6

Gross revenue from willow biomass depending on total biomass production for each harvest date. Price of biomass at gate is considered at $\$ 30.5 / \mathrm{Mg}$ using the EcoWillow 2.0 Cash Flow Model [52]. No additional costs or incomes are considered.

\begin{tabular}{|c|c|c|c|c|c|}
\hline \multirow{3}{*}{$\begin{array}{l}\text { Harvest } \\
\text { date }\end{array}$} & \multicolumn{2}{|c|}{1 st rotation } & \multicolumn{2}{|c|}{ 2nd rotation } & \multirow{2}{*}{$\begin{array}{l}\text { Gross Revenue Over Two } \\
\text { Rotations }\end{array}$} \\
\hline & $\begin{array}{l}\text { Biomass } \\
\text { wet }\end{array}$ & $\begin{array}{l}\text { Gross } \\
\text { Revenue }\end{array}$ & $\begin{array}{l}\text { Biomass } \\
\text { wet }\end{array}$ & $\begin{array}{l}\text { Gross } \\
\text { Revenue }\end{array}$ & \\
\hline & $\mathrm{Mg} \mathrm{ha}^{-1}$ & $\$ /$ ha & $\mathrm{Mg} \mathrm{ha}^{-1}$ & $\$ /$ ha & \$/ha \\
\hline Jun & 65.8 & $2,006.9$ & 82.6 & $2,519.3$ & $4,526.2$ \\
\hline Aug & 71.2 & $2,171.6$ & 79.1 & $2,412.6$ & $4,584.2$ \\
\hline Sep & 76.3 & $2,327.2$ & 76.0 & $2,318.0$ & $4,645.2$ \\
\hline Oct & 82.5 & $2,516.3$ & 89.2 & $2,720.6$ & $5,236.9$ \\
\hline Jan & 80.2 & $2,446.1$ & 93.0 & $2,836.5$ & $5,282.6$ \\
\hline Apr & 91.7 & $2,796.9$ & 96.2 & $2,934.1$ & $5,731.0$ \\
\hline
\end{tabular}

On the other hand, nutrient removal presented a pattern inverse to biomass production, but similar to annual yield, in which higher removals were observed for harvest dates during fall (Oct), followed by summer (Jun, Aug, and Sep) or winter (Jan) harvests, and generally lower in spring (Apr), especially for $\mathrm{N}$ and $P$, which are probably the ones that most often limit plant's growth and receive attention $[62,63]$. Additionally, soil $\mathrm{N}$ and $\mathrm{P}$ levels have shown to decrease significantly after several shrub willow rotations [21]. Our results indicate that the ideal season to perform harvest would be early spring prior to leaf out. Harvesting during early spring then, would ensure higher yields with nutrient export that is lower than harvesting at other times of the year. However, a considerable amount of the nutrients removed during summer and fall harvest dates are present in the leaves, while no leaves are removed during the winter 
and spring harvests. Considering only nutrients removed in the woody biomass, we observe that summer harvest (Jun, Aug, and Sep) removed similar amounts as spring harvest (Apr). We assumed that all leaf material (entire crown of the plant) was harvested during leaf-on stages; however, as previously mentioned, a high proportion of the foliage (data not available) remains on the site to decompose after a commercial mechanized harvest.

Another consideration is the potential to improve existing single pass cut and chip harvesting system through modifications to facilitate the separation of leaves and increase the amount of this material returned to the site or to increase the harvester's flotation to operate during wet soil conditions and avoid leaf-on harvests. This will reduce nutrient removals and improve soil conditions and the quality of the biomass that is collected for conversion to renewable energy products [64].

Commonly, results of nutrient removal are obtained from hand harvests and field trials. Observations of commercial shrub willow harvesting operations have shown that nutrient rich woody and leaf biomass is left on the site. Soil $\mathrm{N}$ and $\mathrm{P}$ levels have been noted to decrease after several rotations [21], which could possibly have impacts on the crop's long-term productivity. For instance, if the efficiency of the harvester is between $7-15 \%$ of the total standing biomass, that would represent $20-35 \%$ of the total nutrient content in the woody above-ground willow biomass [21]. This material would remain on site and offset nutrient losses as they decompose. More research is needed in commercial harvest operations to determine the amount of dropped biomass for harvests at different times of the years (both woody and leaf) and the nutrient content in this biomass, as well as to observe how these operations impact the soil's nutrient levels and the crop's long-term productivity.

\section{Conclusions}

The total biomass production and nutrient removal results from this study support the common recommendation to harvest willow after leaf drop whenever possible. In order to ensure higher biomass production in subsequent rotations, shrub willow crops in NY should be harvested during leaf-off stage when possible. However, site and climatic limitations have forced harvesting operations to occur during the growing season in NY, which could reduce the following rotation's biomass production and possibly remove higher amounts of nutrients from the site. The selection and deployment of cultivars whose biomass production is not compromised by leaf-on harvests could ensure higher yields across rotations. Additionally, the development of methods to separate foliage from woody biomass or to facilitate the harvester's operability during wet soil conditions can contribute to the retention of the foliage on site and/or a wider harvesting window.

The different responses observed by different cultivars depending on harvest date demonstrate that overall shrub willow nutrient management and harvesting methods recommendations will not be effective for all cultivars and sites. Influences of environment and genotype*environment interaction on yield have been observed before, and our results indicate a similar effect of the interaction between cultivar and harvest date on both biomass production and nutrient removal. Hence, harvesting and 
nutrient management guidelines should be recommended by considering site and cultivar characteristics to ensure high yields and maintain soil conditions over multiple rotations. This will contribute to consistent generation of high quality biomass for conversion to renewable energy and potentially provide more gross revenue for the grower.

Further research on the importance of dropped biomass material (both leaf and woody) after mechanical harvest is required. Improvements in the system should focus on increasing harvesting throughput by collecting all merchantable biomass; however, the nutrient content in the dropped biomass might support the growth of future rotations and contribute to the soil nutrient levels and conditions. Harvesting operations should focus on separating foliage and woody biomass, and retaining the nutrient rich foliage and non-merchantable biomass (small twigs and tops of plants) on the site in order to reduce nutrient removal impacts of both leaf-on and leaf-off harvests. Hence new harvesting guidelines and recommendations should be developed based on research and the reality of commercial harvesting operations in the region.

\section{Declarations}

\section{Acknowledgements}

A portion of this research is part of the MASBio (Mid-Atlantic Biomass Consortium for Value-Added Products) project, which is supported by the Agriculture and Food Research Initiative Competitive Grant no. 2020-68012-31881 from the USDA National Institute of Food and Agriculture. This research was also made possible by funding under award \#EE0006638 from the U.S. Department of Energy Bioenergy Technologies Office.

\section{Funding}

A portion of this research is part of the MASBio (Mid-Atlantic Biomass Consortium for Value-Added Products) project, which is supported by the Agriculture and Food Research Initiative Competitive Grant no. 2020-68012-31881 from the USDA National Institute of Food and Agriculture. This research was also made possible by funding under award \#EE0006638 from the U.S. Department of Energy Bioenergy Technologies Office.

\section{Competing Interests}

The authors do not have relevant competing interests associated with this work.

\section{Author Contributions}

All authors contributed to the study concept and design. Timothy Volk and Daniel de Souza are responsible the study conception. Statistical analyses were conducted by Daniel De Souza and Mark Eisenbies. The first draft of the manuscript was written by Daniel de Souza as part of a dissertation 
chapter, and then rewritten with additional and improved analyses by Mark Eisenbies. All authors participated in editing the final draft.

\section{Data Availability}

The authors are willing to share data and collaborate with potential partners upon request.

\section{References}

1. USDOE (2011) U.S. billion-ton update: Biomass supply for a bioenergy and bioproducts industry. ORNL/TM-2011/224. Oak Ridge National Laboratory, Oak Ridge, TN. 227p. Accessed 10 Jan, 2022 https://www1.eere.energy.gov/bioenergy/pdfs/billion_ton_update.pdf

2. USDOE (2016) 2016 Billion-Ton Report: Advancing Domestic Resources for a Thriving Bioeconomy. ORNL/TM-2016/160. In: Langholtz M, Stokes B, Eaton L (eds). Oak Ridge National Laboratory, Oak Ridge, TN, p 448. Accessed 10 Jan, 2022 https://www.energy.gov/sites/default/files/2016/12/f34/2016_billion_ton_report_12.2.16_0.pdf

3. Heavey JP, Volk TA, Syracuse NY (2015) Accessed 10 Jan, 2022 https://www.esf.edu/willow/documents/2NewYorkWillow.pdf

4. Volk TA, Heavey JP, Eisenbies MH (2016) Advances in shrub-willow crops for bioenergy, renewable products, and environmental benefits. Food Energy Secur 5:97-106. https://doi.org/10.1002/fes3.82

5. Buchholz T, Volk T (2013) Profitability of Willow Biomass Crops Affected by Incentive Programs. Bioenergy Res 6:53-64. https://doi.org/10.1007/s12155-012-9234-y

6. Stoof CR, Richards BK, Woodbury PB et al (2015) Untapped Potential: Opportunities and Challenges for Sustainable Bioenergy Production from Marginal Lands in the Northeast USA. Bioenergy Res 8:482-501. https://doi.org/10.1007/s12155-014-9515-8

7. Campbell SP, Frair JL, Gibbs JP, Volk TA (2012) Use of short-rotation coppice willow crops by birds and small mammals in central New York. Biomass Bioenergy 47:342-353. https://doi.org/10.1016/j.biombioe.2012.09.026

8. Smart LB, Cameron KD (2008) Genetic improvement of willow (Salix spp.) as a dedicated bioenergy crop.. In: In: Vermerris W (ed) Genetic improvement of bioenergy crops. Springer, pp 377-396

9. Heavey JP, Volk TA (2014) Living snow fences show potential for large storage capacity and reduced drift length shortly after planting. Agroforest Syst 88:803-814. https://doi.org/10.1007/s10457-0149726-1

10. Mirck J, Volk TA (2010) Response of three shrub willow varieties (Salix spp.) to storm water treatments with different concentrations of salts. Bioresour Technol 101:3484-3492. https://doi.org/10.1016/j.biortech.2009.12.128

11. Fox TR (2000) Sustained productivity in intensively managed forest plantations. For Ecol Manag 138:187-202. https://doi.org/10.1016/S0378-1127(00)00396-0 
12. Garrett LG, Smaill SJ, Addison SL, Clinton PW (2021) Globally relevant lessons from a long-term trial series testing universal hypothesis of the impacts of increasing biomass removal on site productivity and nutrient pools. For Ecol Manag 494:119325. https://doi.org/10.1016/j.foreco.2021.119325

13. Worrell R, Hampson A (1997) The influence of some forest operations on the sustainable management of forest soils - a review. Forestry: An International Journal of Forest Research 70:6185. https://doi.org/10.1093/forestry/70.1.61

14. Heilman P, Norby RJ (1998) Nutrient cycling and fertility management in temperate short rotation forest systems. Biomass Bioenergy 14:361-370. https://doi.org/10.1016/S0961-9534(97)10072-1

15. Richardson J, Björheden R, Hakkila P et al (2002) Bioenergy from Sustainable Forestry: Guiding Principles and Practice. Kluwer Academic Publishers, The Netherlands

16. Burger J, Scott D (2001) Soil interpretations for sustainable forest management in the southeastern United States. In: Soil science-Past, present, and future. Proc. of the Joint Meeting of the Czech Soc. of Soil Sci. and the Soil Sci. Soc. of Am. Prague, Czech Republic. Sept 16-20, 2001. Czech Univ. of Agric., Prague, pp 65-72

17. NRCS (2004) Soil biology and land management. USDA-NRCS, Washington DC

18. Abbas D, Current D, Phillips $M$ et al (2011) Guidelines for harvesting forest biomass for energy: A synthesis of environmental considerations. Biomass Bioenergy 35:4538-4546. https://doi.org/10.1016/j.biombioe.2011.06.029

19. Eisenbies M, Volk T, Amidon T et al (2020) Improved Advanced Biomass Logistics Utilizing Woody and other Feedstocks in the Northeast and Pacific Northwest. https://doi.org/10.2172/1768177. Final Report:EE0006638 USDOE-EERE

20. Eisenbies MH, Volk TA, Posselius J et al (2014) Evaluation of a Single-Pass, Cut and Chip Harvest System on Commercial-Scale, Short-Rotation Shrub Willow Biomass Crops. Bioenergy Res 7:15061518. https://doi.org/10.1007/s12155-014-9482-0

21. de Souza DPL (2019) "Nutrient Removal in Willow Biomass Crops is Impacted Over Multiple Rot" by Daniel Pegoretti Leite de Souza. Dissertation, State University of New York College of Environmental Science and Forestry

22. Berhongaray G, El Kasmioui O, Ceulemans R (2013) Comparative analysis of harvesting machines on an operational high-density short rotation woody crop (SRWC) culture: One-process versus twoprocess harvest operation. Biomass Bioenergy 58:333-342. https://doi.org/10.1016/j.biombioe.2013.07.003

23. Boyd J, Christersson L, Dinkelbach L (2000) Energy from Willow. Scottish Agricultural College Accessed 10 Jan, 2022. https://www.ecologieforum.eu/download/Willow_s.pdf

24. Eisenbies M, Volk T, DeSouza D, Kallen K (2020) Cut and chip harvester material capacity and fuel performance on commercial-scale willow fields for varying ground and crop conditions. https://doi.org/DOl:10.1111/gcbb.12679. Global Change Biology Bioenergy

25. Hytonen J (1996) Biomass production and nutrition of short rotation plantations. Dissertation, The Finish Forest Research Institute 
26. Ceulemans R, McDonald AJS, Pereira JS (1996) A comparison among eucalypt, poplar and willow characteristics with particular reference to a coppice, growth-modelling approach. Biomass Bioenergy 11:215-231. https://doi.org/10.1016/0961-9534(96)00035-9

27. Steinbeck K (1978) Intensively managed short rotation coppice forests. In: Choong ET, Chamber JL (eds) 1978: Energy and the Southern Forest. Baton Rouge, LA

28. Strong TF, Zavitovski J (1983) Effect of harvesting season on hybrid poplar coppicing. In: Hansen EA (ed) Intensive Plantation Culture: 12 years Research. $p 4$

29. de Souza PL, Gallagher D, Mitchell T et al (2016) Determining the effects of felling method and season of year on the regeneration of short rotation coppice. International Journal of Forest Engineering 27:53-65. https://doi.org/10.1080/14942119.2015.1135616

30. Hytönen J (1994) Effect of cutting season, stump height and harvest damage on coppicing and biomass production of willow and birch. Biomass Bioenergy 6:349-357. https://doi.org/10.1016/0961-9534(94)E0029-R

31. USDA Natural Resources Conservation Service Web Soil Survey. https://websoilsurvey.sc.egov.usda.gov/App/HomePage.htm

32. Hanna WE (1981) Soil survey of Madison County. USDA Soil Conservation Service, Cornell University Agricultural Experiment Station, New York

33. Arevalo C, Volk T, Bevilacqua E, Abrahamson L (2007) Development and validation of aboveground biomass estimations for four Salix clones in central New York. Biomass Bioenergy 31:1-12. https://doi.org/10.1016/j.biombioe.2006.06.012

34. ASABE (2012) Moisture measurement - ANSI/ASABE Standards S358.2. American Society of Agricultural and Biological Engineers, St Joseph, MI

35. Stehman SV, Meredith MP (1995) Practical analysis of factorial experiments in forestry.Can J For Res446-461

36. Carmer S, Swanson M (1973) An evaluation of ten pairwise multiple comparison procedures by Monte Carlo methods. J Am Stat Assoc 68:66-74

37. SAS Institute (2009) SAS/STAT 9.2 User's Guide, 2nd edn. SAS Institute Inc., Cary, NC

38. Sleight NJ, Volk TA, Johnson GA et al (2016) Change in Yield Between First and Second Rotations in Willow (Salix spp.) Biomass Crops is Strongly Related to the Level of First Rotation Yield. Bioenergy Res 9:270-287. https://doi.org/10.1007/s12155-015-9684-0

39. Fabio ES, Smart LB (2018) Effects of nitrogen fertilization in shrub willow short rotation coppice production - a quantitative review. GCB Bioenergy 10:548-564. https://doi.org/10.1111/gcbb.12507

40. Eisenbies MH, Volk TA, Posselius J et al (2014) Evaluation of a Single-Pass, Cut and Chip Harvest System on Commercial-Scale, Short-Rotation Shrub Willow Biomass Crops. Bioenergy Res. https://doi.org/10.1007/s12155-014-9482-0

41. Tharakan PJ, Robison DJ, Abrahamson LP, Nowak CA (2001) Multivariate approach for integrated evaluation of clonal biomass production potential. Biomass Bioenergy 21:237-247. 
https://doi.org/10.1016/S0961-9534(01)00038-1

42. Weih M (2009) Genetic and environmental variation in spring and autumn phenology of biomass willows (Salix spp.): effects on shoot growth and nitrogen economy. Tree Physiol 29:1479-1490. https://doi.org/10.1093/treephys/tpp081

43. Fixen P, Bruulsema T, Jensen T et al (2010) The fertility of North American soils, 2010. Better Crops Plant Food 94:6-8

44. Fromm J (2010) Wood formation of trees in relation to potassium and calcium nutrition. Tree Physiol 30:1140-1147. https://doi.org/10.1093/treephys/tpq024

45. Ducrey M, Turrel M (1992) Influence of cutting methods and dates on stump sprouting in Holm oak (Quercus ilex L) coppice. Annales des Sciences Forestières 49:449-464. https://doi.org/10.1051/forest:19920502

46. Bollmark L (2000) Accumulation and Mobilisation of Nutrient Reserves in Salix viminalis. Doctor's dissertation

47. von Fircks Y, Ericsson T, Sennerby-Forsse L (2001) Seasonal variation of macronutrients in leaves, stems and roots of Salix dasyclados Wimm. grown at two nutrient levels. Biomass Bioenergy 21:321-334. https://doi.org/10.1016/S0961-9534(01)00045-9

48. Eisenbies MH, Volk TA, Posselius J et al (2014) Quality and Variability of Commercial-Scale Short Rotation Willow Biomass Harvested Using a Single-Pass Cut-and-Chip Forage Harvester. https://doi.org/10.1007/s12155-014-9540-7. BioEnergy Research

49. Kenney KL, Smith WA, Gresham GL, Westover TL (2013) Understanding biomass feedstock variability. Biofuels 4:111-127. https://doi.org/10.4155/bfs.12.83

50. Adegbidi HG, Volk TA, White EH et al (2001) Biomass and nutrient removal by willow clones in experimental bioenergy plantations in New York State. Biomass Bioenergy 20:399-411

51. Hangs RD, Schoenau JJ, Van Rees KCJ et al (2014) First Rotation Biomass Production and Nutrient Cycling within Short-Rotation Coppice Willow Plantations in Saskatchewan, Canada. Bioenergy Res 7:1091-1111. https://doi.org/10.1007/s12155-014-9452-6

52. Labrecque M, Teodorescu TI (2003) High biomass yield achieved by Salix clones in SRIC following two 3-year coppice rotations on abandoned farmland in southern Quebec, Canada. Biomass Bioenergy 25:135-146. https://doi.org/10.1016/S0961-9534(02)00192-7

53. Quaye AK, Volk TA, Hafner $S$ et al (2011) Impacts of paper sludge and manure on soil and biomass production of willow. Biomass Bioenergy 35:2796-2806.

https://doi.org/10.1016/j.biombioe.2011.03.008

54. Dickmann DI, Isebrands JG, Eckenwalder JE, Richardson JE (2001) Poplar Culture in North America. NRC Research Press, Ottawa, Canada

55. Lodhiyal LS, Lodhiyal N (1997) Nutrient Cycling and Nutrient Use Efficiency in Short Rotation, High Density Central Himalayan Tarai Poplar Plantations.Annals of Botany517-527 
56. Ericsson T (1995) Nutrient Dynamics and Requirements of Forest Crops. N Z J Forest Sci 24(2/3):133-168

57. Fabio ES, Volk TA, Miller RO et al (2017) Contributions of environment and genotype to variation in shrub willow biomass composition. Ind Crops Prod 108:149-161.

https://doi.org/10.1016/j.indcrop.2017.06.030

58. Peterson GM, Galbraith JK (1932) The Concept of Marginal Land. J Farm Econ 14:295-310. https://doi.org/10.2307/1230112

59. Khanna M, Chen L, Basso B et al (2021) Redefining marginal land for bioenergy crop production. GCB Bioenergy 13:1590-1609. https://doi.org/10.1111/gcbb.12877

60. Heavey, Syracuse NY (and Volk 2014) Accessed 10 Jan, 2022. https://www.esf.edu/willow/documents/4CropProductionScenarios.pdf

61. Eisenbies M, Volk T, de Souza D, Hallen K (2020) Cut and chip harvester material capacity and fuel performance on commercial-scale willow fields for varying ground and crop conditions. GCB Bioenergy 9:161-179. https://doi.org/10.1111/gcbb.12679

62. Hausenbuiller RL (1978) Soil Science: Principles and Practices, Second Edition. Wm. C. Brown Company Publishers, United States of America

63. Burger JA (2002) Soil and long-term site productivity values.. In: In: Richardson J, Björheden R, Hakkila P et al (eds) Bioenergy from Sustainable Forestry: Guiding Principles and Practice. Kluwer Academic Publishers, Netherlands

64. Emerson RM, Hernandez S, Williams CL et al (2018) Improving bioenergy feedstock quality of high moisture short rotation woody crops using air classification. Biomass Bioenergy 117:56-62. https://doi.org/10.1016/j.biombioe.2018.07.015

\section{Figures}




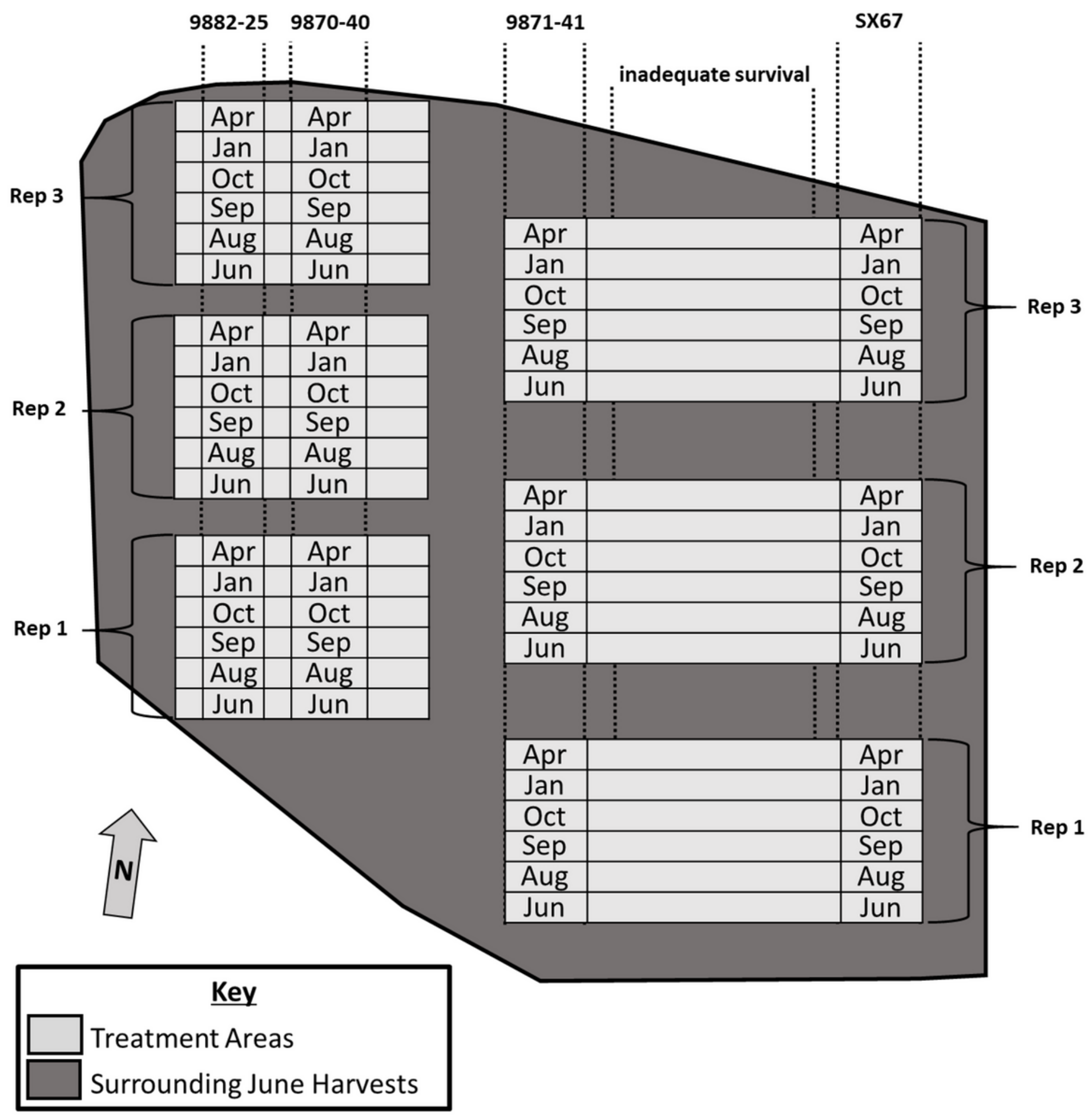

Figure 1

Schematic of the experiment with the four cultivars used in the study and layout of plots and replications. Hashed area was harvested at the same time as the first harvest date (Jun). Grey areas indicate the treatment plots associated with the harvest dates, and areas that were treated but not included due to low survival. 


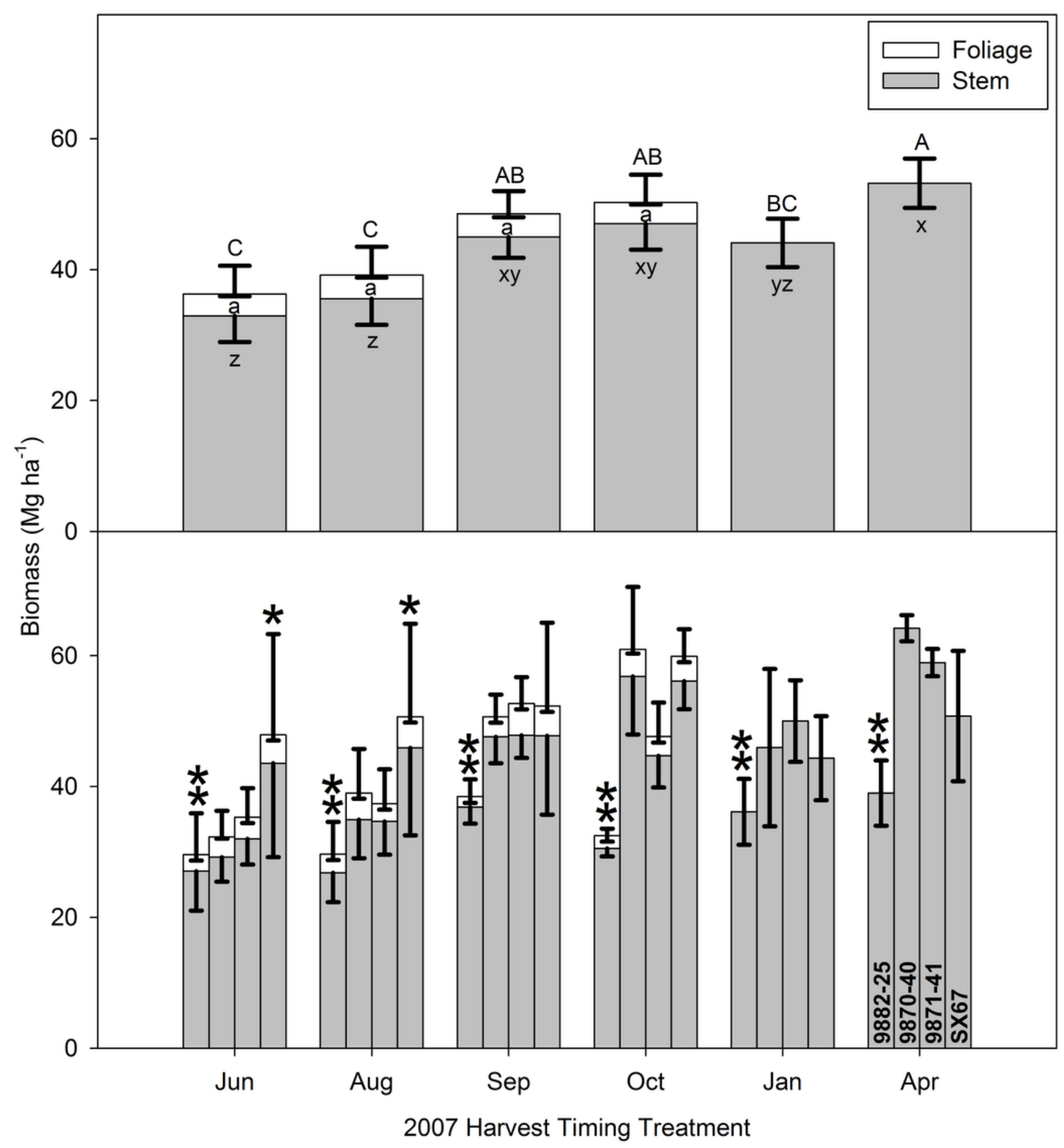

Figure 2

(TOP) Mean willow stem and foliage biomass production for the first rotation time-of-harvest treatments that occurred on the prescribed treatment areas between June 2007 and April 2008. Letters indicate significant differences between total biomass (upper case), foliar biomass (lower case a-b-c), and stem biomass (lower case $x-y-z)$. Error bar indicates the standard error for the total biomass (upward), and the stem and foliage components (downward). (BOTTOM) Sets of bars showing stem and foliage biomass 
for individual cultivars as labeled on the rightmost group. Treatment periods containing significant differences among cultivars are indicated by asterisks $(*)$.

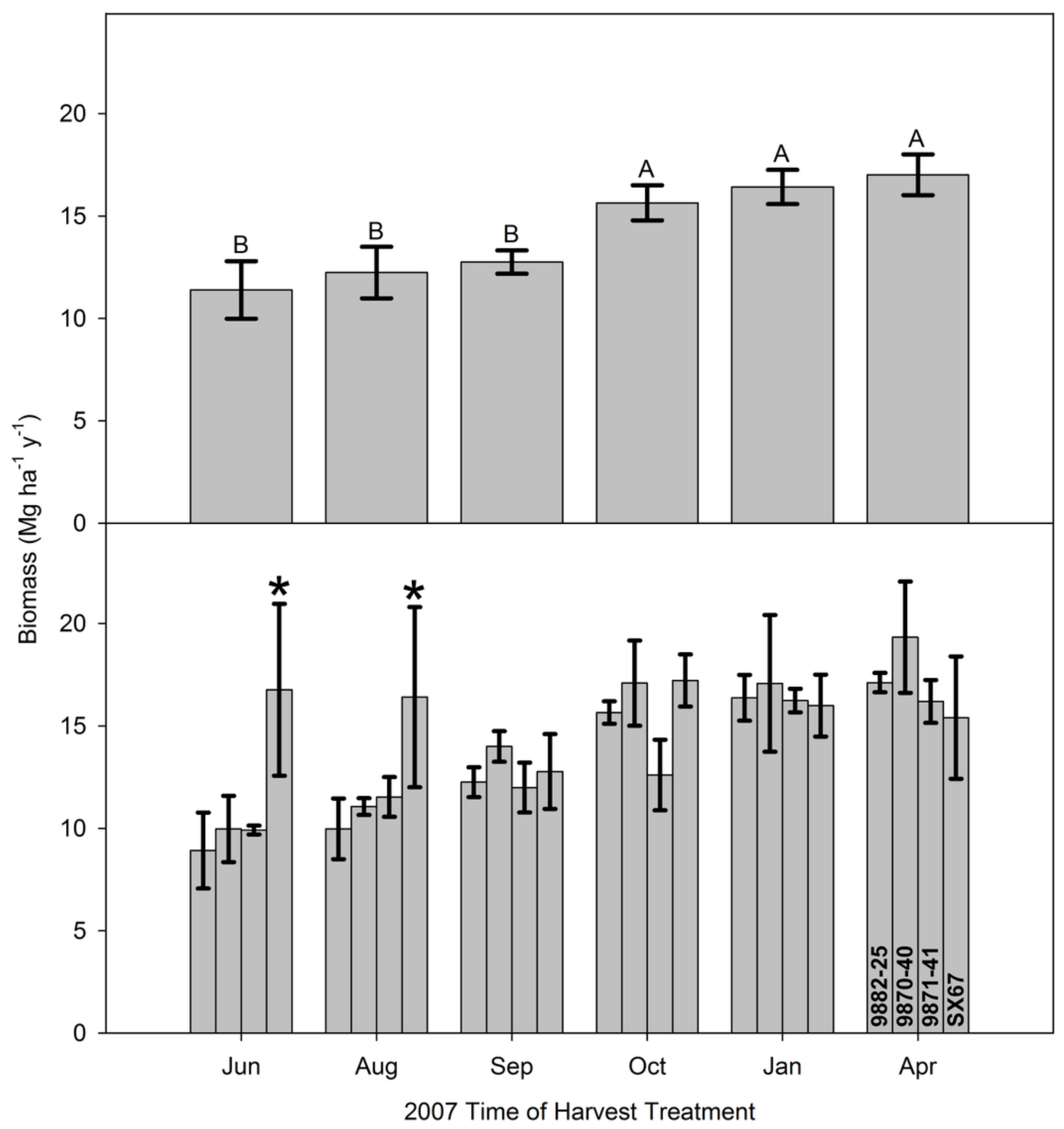

Figure 3

(TOP) Mean annual yield for the leaf-off, second rotation harvest within the time-of-harvest treatments areas in Dec 2011. Biomass amounts shared letters are not significantly different. Error bars indicate the 
standard error. (BOTTOM) Sets of bars showing stem and foliage biomass for individual cultivars as labeled on the rightmost group. Treatment periods containing significant differences among cultivars are indicated by asterisks $(*)$.

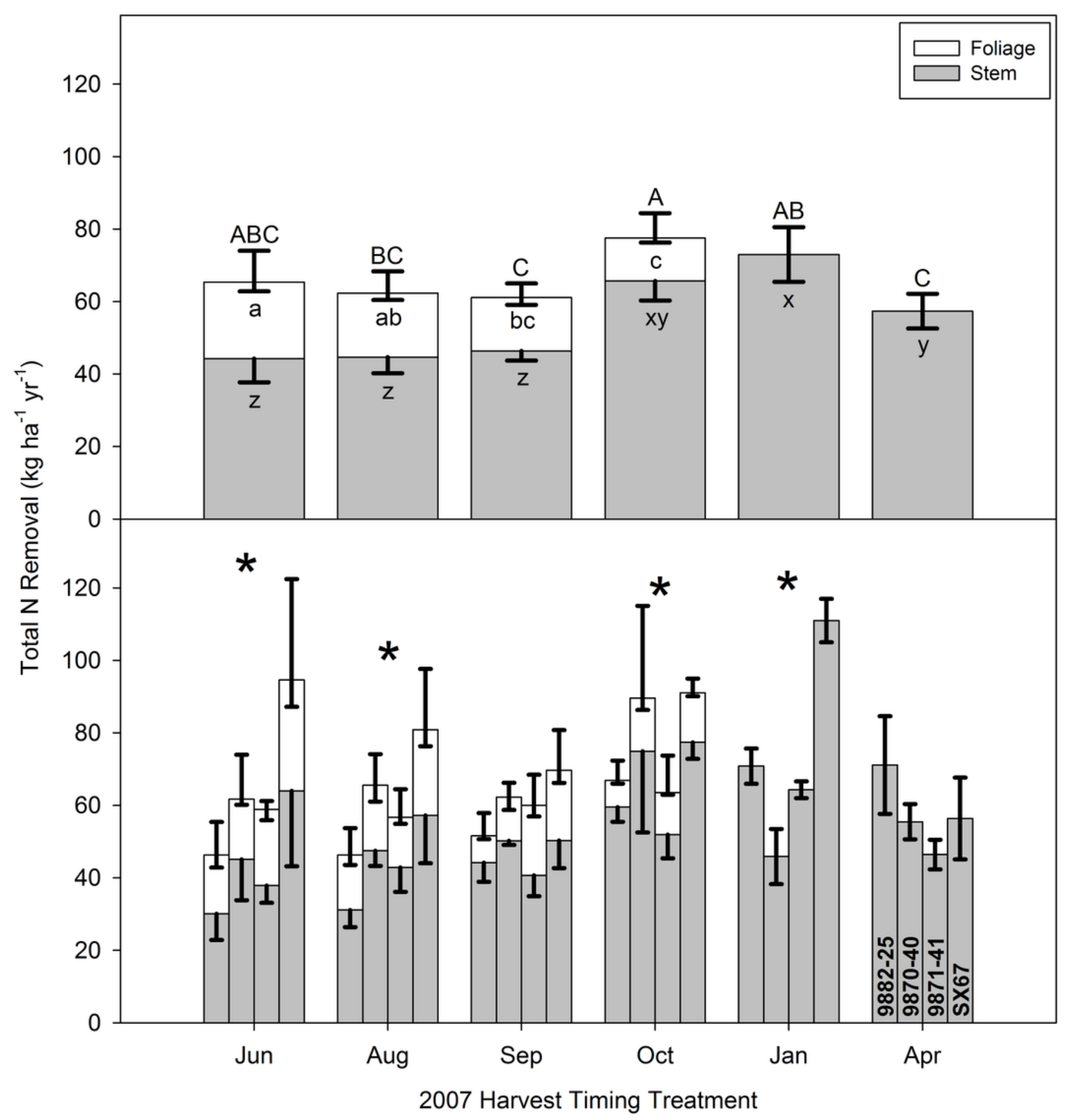

Figure 4 
(TOP) Nitrogen removal in the form of stem and foliage biomass for the first rotation time-of-harvest treatments that occurred on the prescribed treatment areas between June 2007 and April 2008. Letters indicate significant differences between total removal (upper case), foliar removal (lower case a-b-c), and stem removal (lower case $\mathrm{x}-\mathrm{y}-\mathrm{z}$ ). Error bar indicates the standard error for the total removal (upward), and the stem and foliage components (downward). (BOTTOM) Sets of bars showing stem and foliage biomass for individual cultivars as labeled on the rightmost group. Treatment periods containing significant differences among cultivars are indicated by asterisks $(*)$.

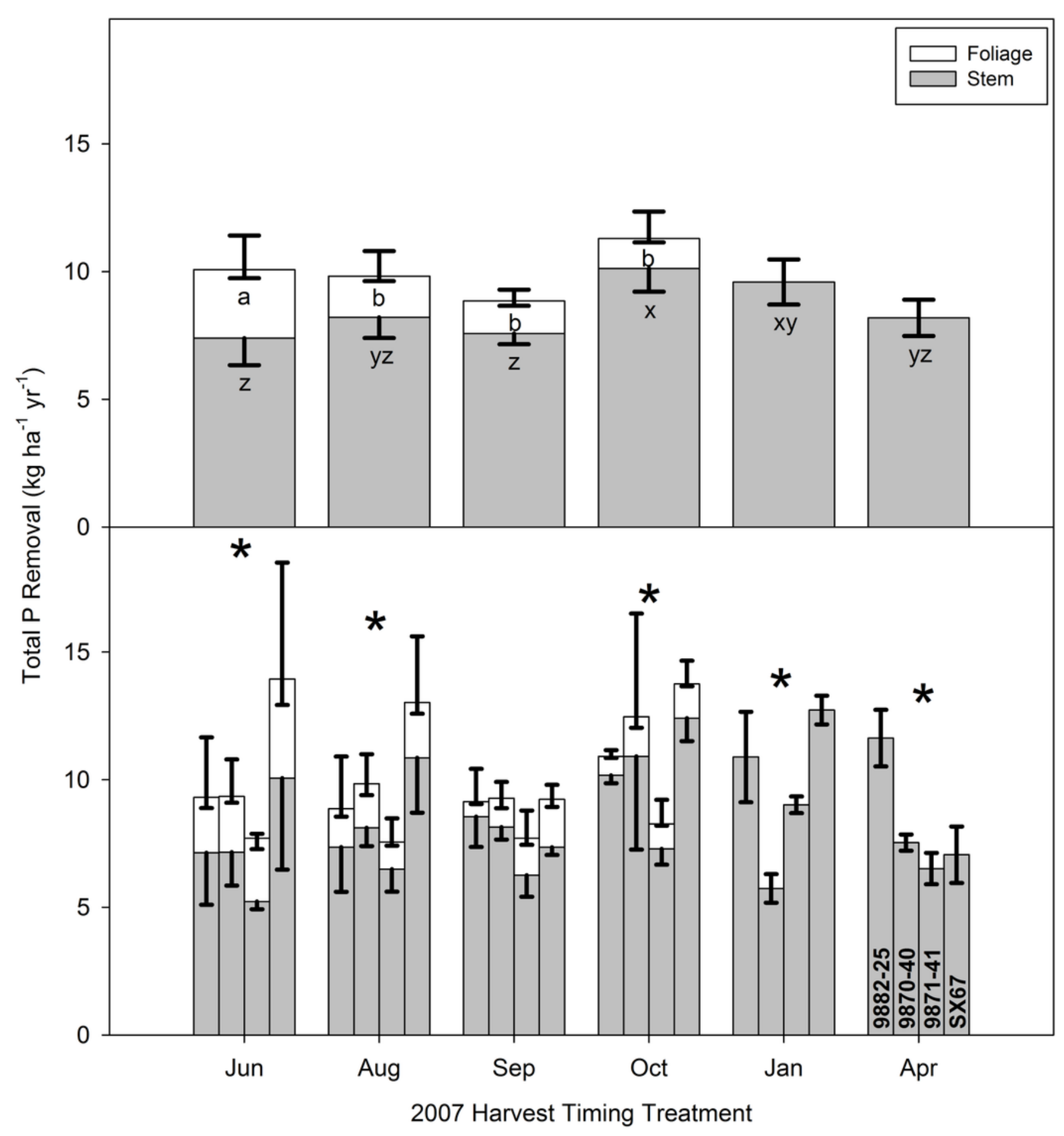




\section{Figure 5}

(TOP) Phosphorus removal in the form of stem and foliage biomass for the first rotation time-of-harvest treatments that occurred on the prescribed treatment areas between June 2007 and April 2008. Letters indicate significant differences between foliar removal (lower case a-b-c), and stem removal (lower case $x-y-z)$. Error bar indicates the standard error for the total removal (upward), and the stem and foliage components (downward). (BOTTOM) Sets of bars showing stem and foliage biomass for individual cultivars as labeled on the rightmost group. Treatment periods containing significant differences among cultivars are indicated by asterisks $\left({ }^{*}\right)$. 


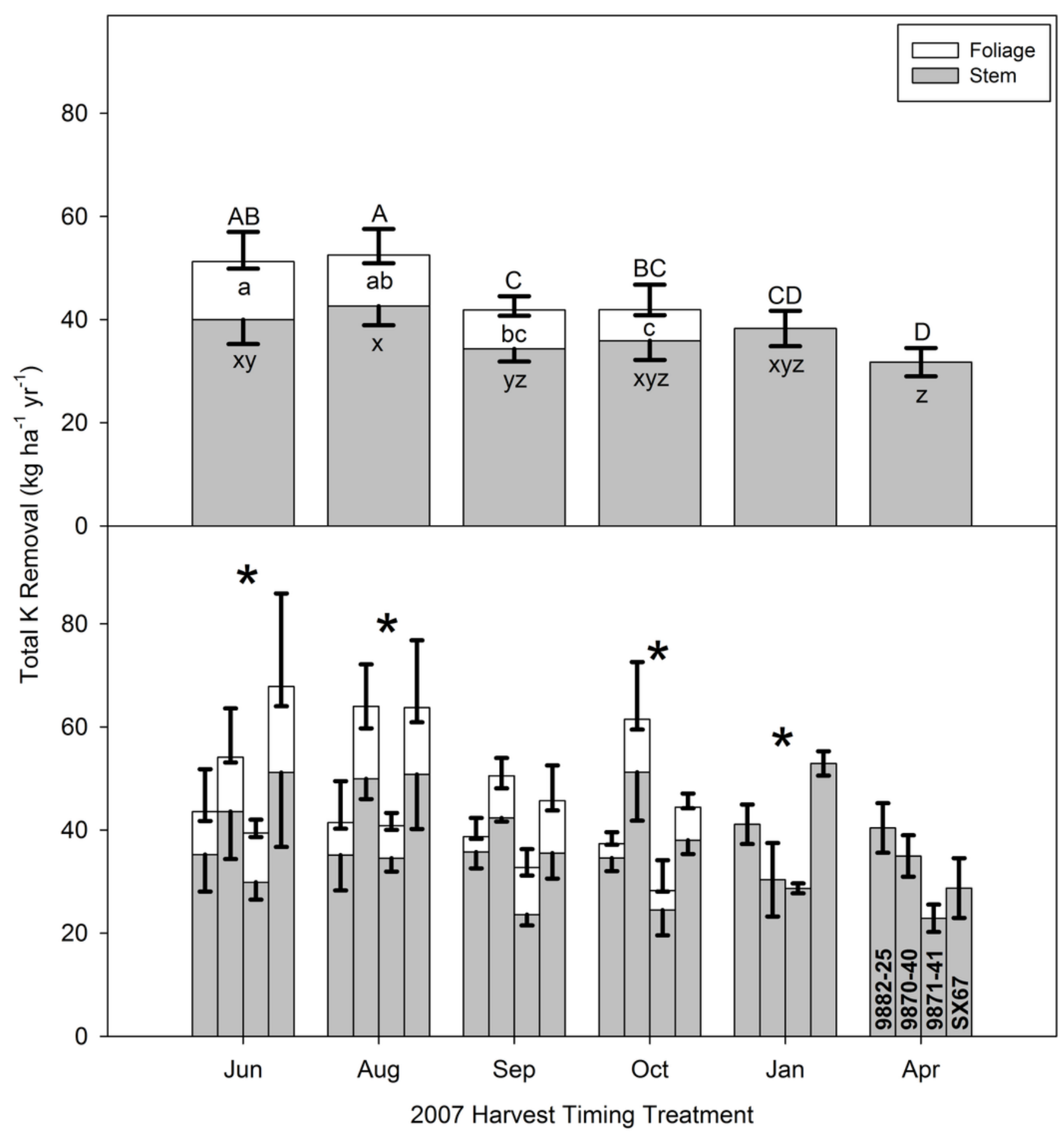

Figure 6

(TOP) Potassium removal in the form of stem and foliage biomass for the first rotation time-of-harvest treatments that occurred on the prescribed treatment areas between June 2007 and April 2008. Letters indicate significant differences between total removal (upper case), foliar removal (lower case a-b-c), and stem removal (lower case $x-y-z)$. Error bar indicates the standard error for the total removal (upward), and the stem and foliage components (downward). (BOTTOM) Sets of bars showing stem and foliage 
biomass for individual cultivars as labeled on the rightmost group. Treatment periods containing significant differences among cultivars are indicated by asterisks $\left({ }^{*}\right)$.

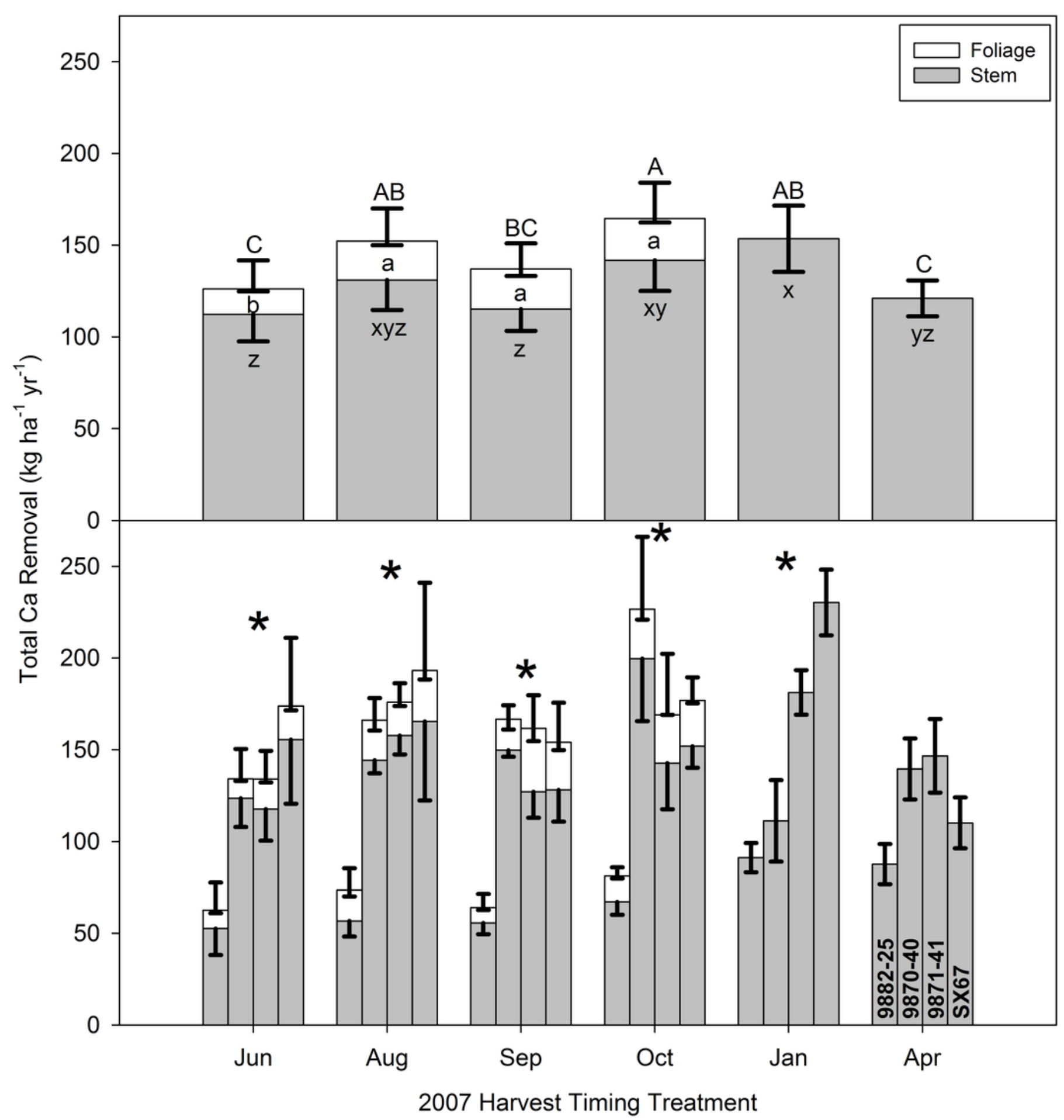

Figure 7

(TOP) Calcium removal in the form of stem and foliage biomass for the first rotation time-of-harvest treatments that occurred on the prescribed treatment areas between June 2007 and April 2008. Letters 
indicate significant differences between total removal (upper case), foliar removal (lower case a-b-c), and stem removal (lower case $x-y-z)$. Error bar indicates the standard error for the total removal (upward), and the stem and foliage components (downward). (BOTTOM) Sets of bars showing stem and foliage biomass for individual cultivars as labeled on the rightmost group. Treatment periods containing significant differences among cultivars are indicated by asterisks $(*)$.

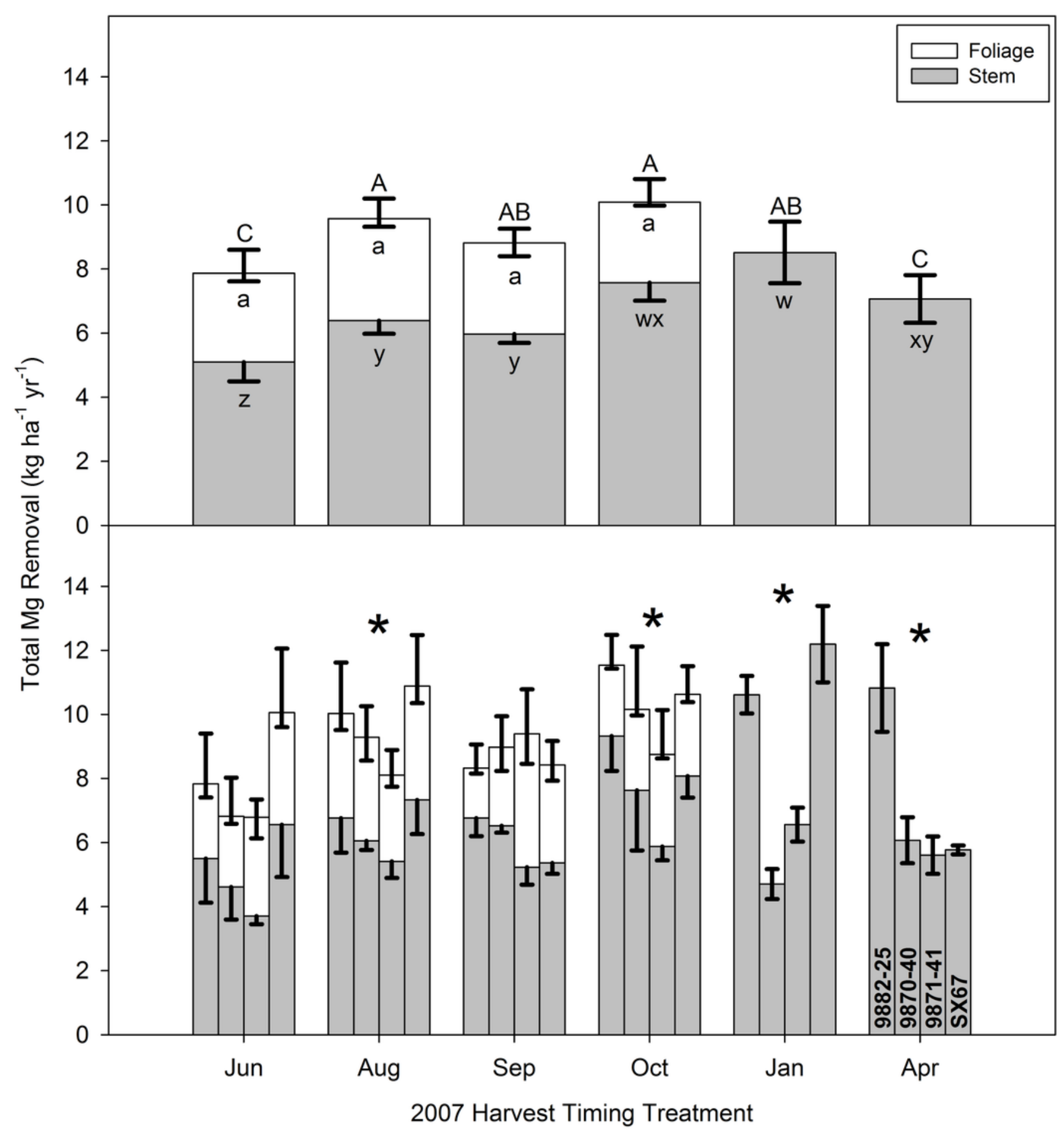

Figure 8 
(TOP) Magnesium removal in the form of stem and foliage biomass for the first rotation time-of-harvest treatments that occurred on the prescribed treatment areas between June 2007 and April 2008. Letters indicate significant differences between total removal (upper case), foliar removal (lower case a-b-c), and stem removal (lower case $x-y-z$ ). Error bar indicates the standard error for the total removal (upward), and the stem and foliage components (downward). (BOTTOM) Sets of bars showing stem and foliage biomass for individual cultivars as labeled on the rightmost group. Treatment periods containing significant differences among cultivars are indicated by asterisks $(*)$.

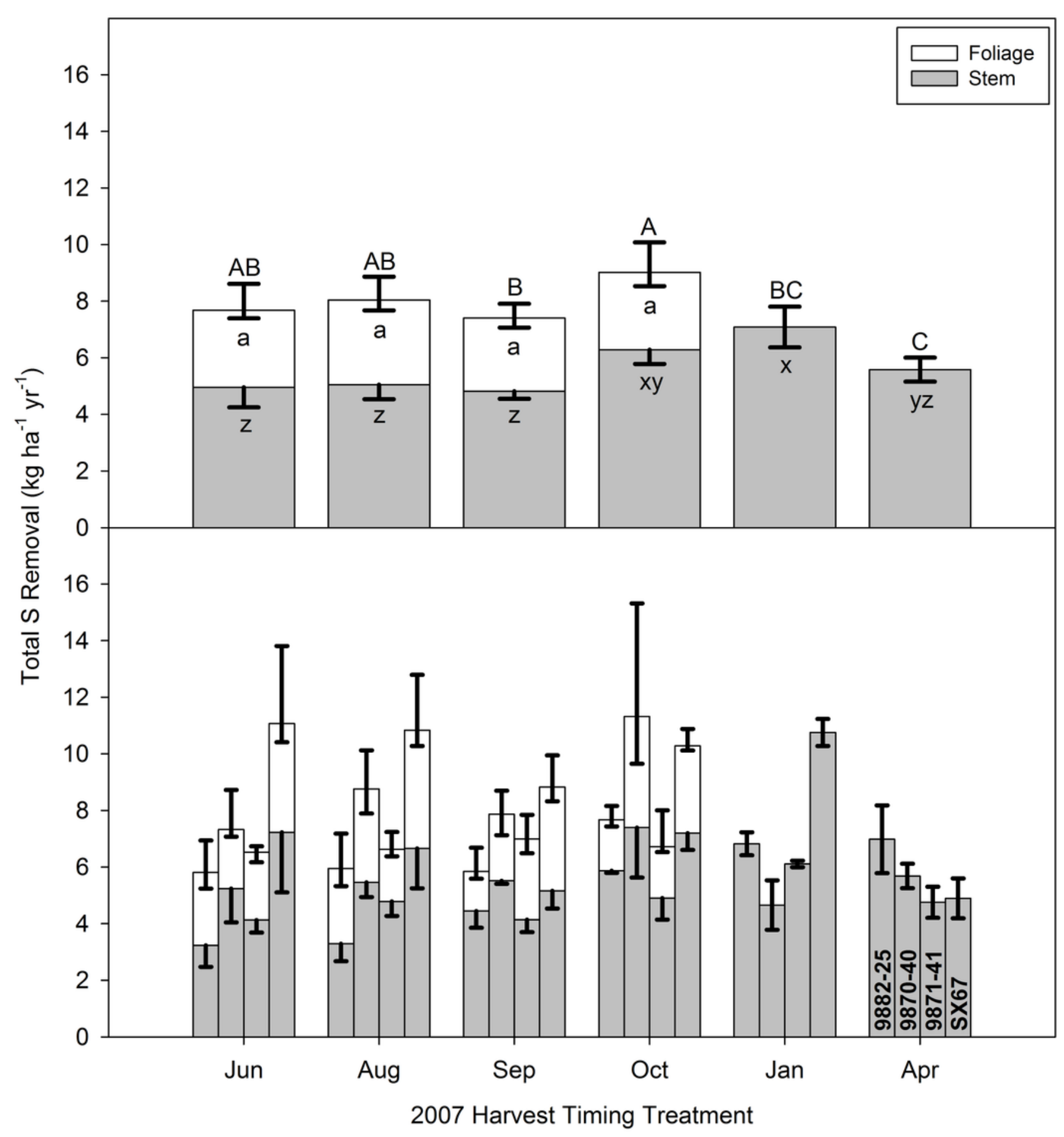




\section{Figure 9}

(TOP) Sulfur removal in the form of stem and foliage biomass for the first rotation time-of-harvest treatments that occurred on the prescribed treatment areas between June 2007 and April 2008. Letters indicate significant differences between total removal (upper case), foliar removal (lower case a-b-c), and stem removal (lower case $x-y-z)$. Error bar indicates the standard error for the total removal (upward), and the stem and foliage components (downward). (BOTTOM) Sets of bars showing stem and foliage biomass for individual cultivars as labeled on the rightmost group. Treatment periods containing significant differences among cultivars are indicated by asterisks $\left({ }^{*}\right)$.

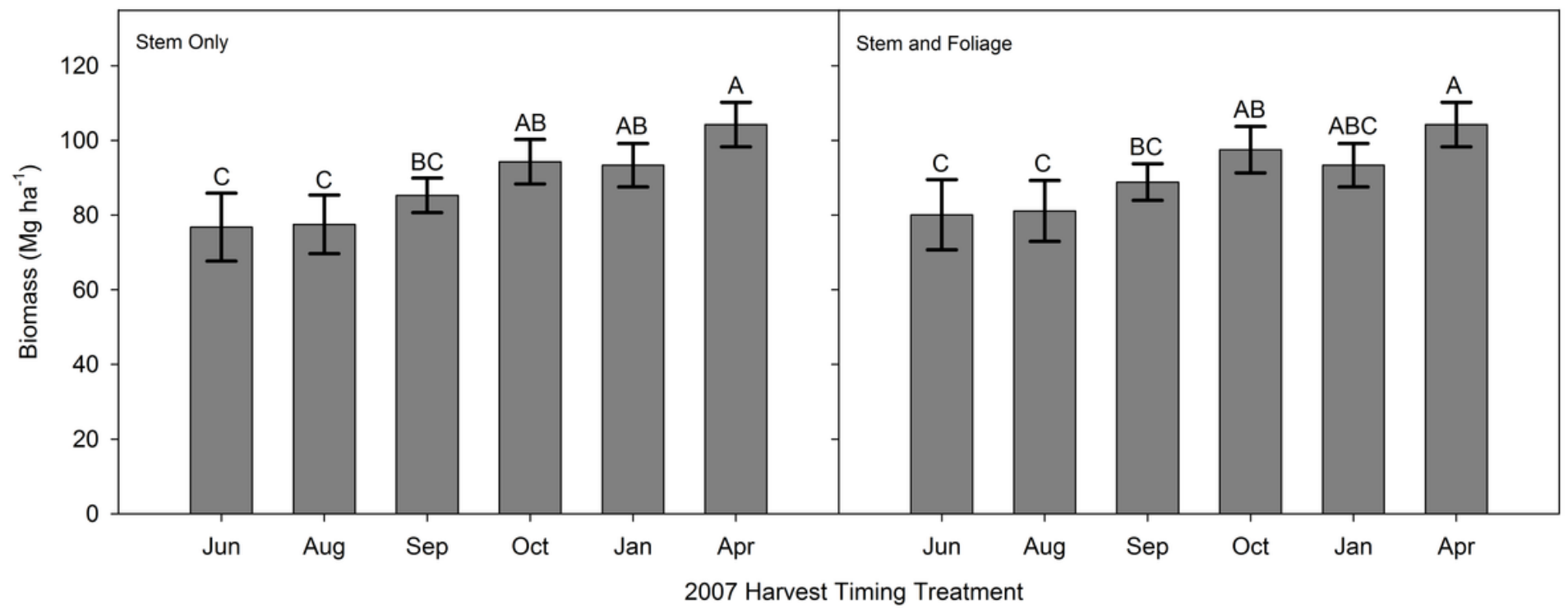

Figure 10

Combined biomass yield for both 2007 and 2011 with and without foliage. Letters indicate significant differences within each graph only. 